\title{
MEMORIA DEL PUEBLO KAWÉSQAR A TRAVÉS DE UNA HISTORIA DE VIDA
}

ÁNGEL ACUÑA D. *

\section{RESUMEN}

El presente trabajo es un homenaje a la memoria y al conocimiento local, al tiempo que un intento de poner en valor la herencia del conocimiento de un pueblo, o mejor aún, de la experiencia de un pueblo en vías de desaparición. A través de la autobiografía asistida recogida de doña Gabriela Paterito (mujer kawésqar de algo más de 70 años y residente en Puerto Edén) reflexionamos sobre los aspectos más sobresalientes de su vida, ordenados de acuerdo a una serie de unidades de análisis, como son: la adaptación ecológica, la búsqueda y obtención de recursos, los valores y las relaciones sociales, y la mentalidad y el cambio social. Es este un esfuerzo de síntesis que tiene por finalidad ofrecer el bagaje de conocimiento sociocultural que explícita o implícitamente se desprende de su testimonio y afecta a la vida cotidiana de su pueblo, de los hombres y mujeres kawésqar con quién compartió el espacio, el tiempo y muchas situaciones desde aproximadamente 1945 hasta 2009.

PALABRAS CLAVE: kawésqar, memoria, historia, cultura.

\section{MEMORY OF THE KAWÉSQAR PEOPLE TROUFH A LIFE HISTORY}

\begin{abstract}
The present work is a tribute to the memory and to local knowledge, same time that an attempt of putting in value the inheritance of the knowledge of some people, or better still, of the experience of some people in routes of disappearance. Across the assisted autobiography gathered from Mrs. Gabriela Paterito (kawésqar woman of about 70 years old and resident in Port Eden)we consider about the most remarkables aspects of his life, been ordained from agreement to a series of units of analysis such as:the ecological adjustment, the search and obtaining of resources, the values and the social relations, and the mentality and the social change.This one is an effort of synthesis which purpose offer the socioculturalknowledgebaggage which explicitly or implicitly leaves his testimony and concerns the daily life of his people, of the men and women kawésqar with whom he shared the space, the time and many situations from approximately 1945 until 2009.
\end{abstract}

KEY WORDS: kawésqar, memory, history, culture. 


\section{INTRODUCCIÓN}

La historia de vida como relato con fines de utilización científica ha sido un medio muy empleado a lo largo del siglo XX (Thomas y Znaniecki 1918-1920; Radin 1920, 1926; Alport 1942; Simmons 1942; Garfinkel 1967; Balan 1975; Harré y De Waele 1979; Catani y Maze 1982; cfr. Sarabia 1986), tanto desde un enfoque idiográfico particularista para acceder al conocimiento local, como nomotético comparativo para alcanzar una mejor comprensión de la condición humana. Sea como sea, a través de ella las personas nos cuentan cómo se han desenvuelto en su contexto ambiental y sociocultural a lo largo del tiempo, y cómo construyen su mapa cognitivo en dicho contexto.

Estrategia especialmente adecuada para acceder al discurso de personas no acostumbradas a responder las preguntas concretas que son propias de una entrevista intensiva, focalizada sobre temas específicos. Quienes acostumbran conversar como forma de entretenimiento para pasar el tiempo, les suele resultar violento participar de interrogatorios donde se les requiere precisión en las respuestas. Por tal motivo, para hacer fluir el conocimiento de tales personas, es preciso dialogar en la forma que habitualmente lo hacen, dejando hablar con libertad y contextualizando ampliamente los acontecimientos. En este sentido, las historias de vida pueden desempeñar un papel privilegiado.

Así lo entendimos en nuestra investigación, una vez situados en contexto de interacción con la población kawésqar de Puerto Edén, en donde permanecimos durante cuatro meses, entre octubre de 2008 y febrero de 2009. Afortunadamente allí encontramos a una persona ejemplar para realizar

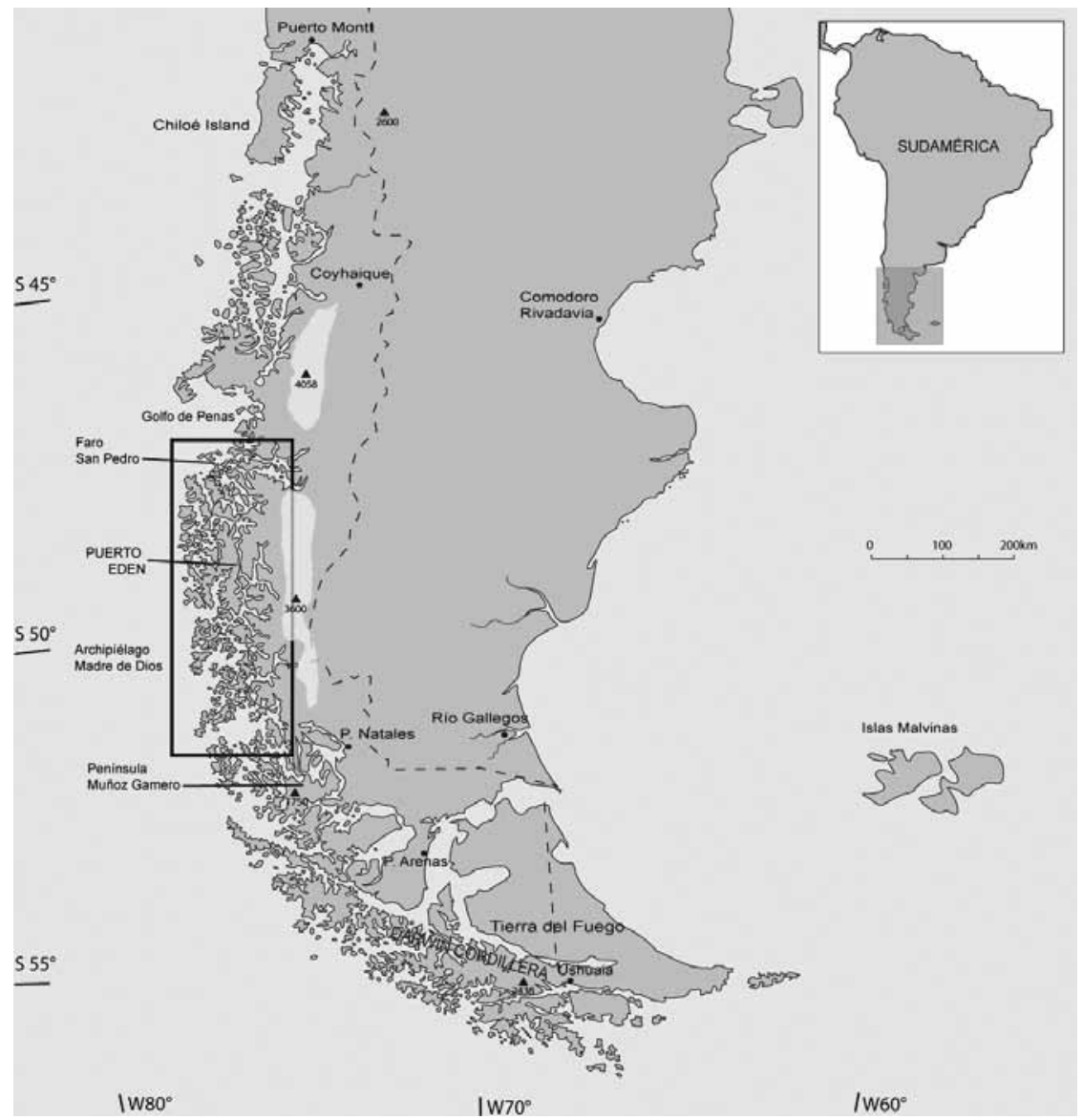

Fig. 1. Delimitación del espacio ecológico referido en este trabajo dentro del Archipiélago Patagónico. 


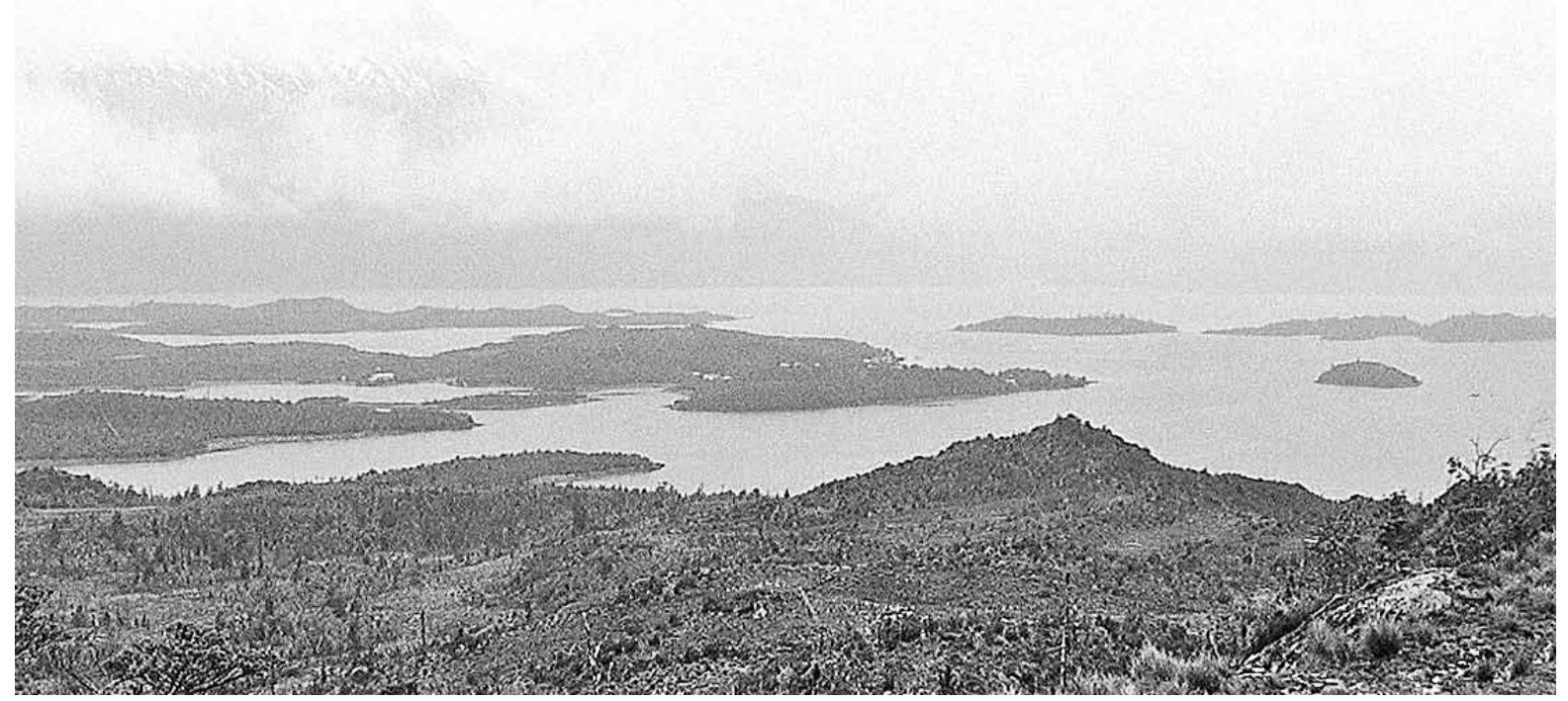

Fig. 2. Entorno de Puerto Edén.

este tipo de trabajo, familiarizada en colaborar con proyectos de investigación lingüística, Doña Gabriela reunía todos los requisitos: persona de algo más de 70 años de edad, arraigada en los canales patagónicos de donde no ha querido salir, con gran conocimiento práctico de las costumbres de su pueblo, testigo privilegiado del proceso de cambio y asimilación experimentado a partir de 1940, honesta y sincera, con extraordinaria memoria de largo plazo y gran elocuencia. A través de su testimonio, recogido en 50 horas de grabación y transcrito en más de 200 páginas, tratamos de recomponer de manera sistemática y cronológica el modo de vida y la trasformación a la que ha estado sujeto su pueblo. La verificación de los datos obtenidos en su historia de vida fue contrastada mediante las conversaciones mantenidas con ella misma de manera informal y coloquial, al margen de las grabaciones; con los datos obtenidos de otras personas, tanto kawésqar como no kawésqar, que poseen gran conocimiento de la vida en los canales; así como con mi propia observación sobre el terreno de las huellas del pasado y presente; y con la pertinente revisión bibliográfica. Con todo ello y aunque se trate de un caso concreto, el de una mujer valerosa, resulta relevante y significativo como aproximación al proceso histórico que ha vivido junto a su pueblo en el espacio ecológico referido (desde el faro de San Pedro hasta el archipiélago Madre de Dios) - Fig. 1.

Si bien la investigación arqueológica sobre los pueblos amerindios que habitaron esta parte del continente ha dado buenos resultados y sigue en desarrollo, probablemente con mucho aún por descubrir (Laming-Emperaire 1972; Legoupil 198586, 1997, 2000; Massone 1987; Aspillaga et al 1999; Piana \& Orquera 2004). Así como la investigación histórica desde tiempos de los primeros contactos con los europeos y posterior colonización hasta la actualidad (Martinic 1989, 2004, 2006). E incluso los estudios lingüísticos han sido y siguen siendo esclarecedores (Clairis 1985; Aguilera 2001). Entre los trabajos etnográficos tan solo encontramos dos obras clásicas sobre Kawésqar: la de Gusinde (1991 [1974]), referida a la península de Muñoz Gamero (lugar próximo a Puerto Natales), y especialmente la de Emperaire (1963), situada en el entorno de Puerto Edén (en la parte media de la isla Wellington). Más allá de ellas tan solo existen aportes esporádicos de 
navegantes, exploradores y misioneros (Córdoba 1787; Darwin 1997[1921]; De Agostini 1929); y más acá estudios de escasa envergadura y alguna que otra biografía nativa (Vega 1995).

El estilo discursivo del relato de doña Gabriela podemos situarlo entre la autobiografía y la memoria, aunque está mucho más cerca de la primera. Autobiografía porque se trata de un relato retrospectivo de su propia vida como eje de la trama. Y memoria porque con frecuencia pone énfasis también en hechos externos a su propia persona, que son significativos para ella. Estaríamos próximos sobre todo a lo que Rom Harré \& De Waele (1979; cfr. Sarabia 1986) denominaron autobiografía asistida, acompañada y verificada por el propio investigador, en donde se presenta finalmente un buen número de pasajes o acontecimientos encadenados y muy significativos de su historia de vida total, no temática o focalizada sobre un tema en concreto, ni tampoco preparada, ya que es fiel a la literalidad y cronología de su relato, sin cortes ni composiciones.

A fin de aproximar más al lector a la protagonista de este trabajo, se ha respetado la literalidad de sus testimonios. Tal vez cueste comprender algunas palabras o ciertas frases, pero entendemos que constituye un valor añadido respetar la trascripción ortográfica de los relatos, de acuerdo a cómo fueron expresados, en un castellano no aprendido en la escuela sino a través de la interacción cotidiana durante años con hispanohablantes.

Los datos registrados nos permitirán reflexionar sobre los aspectos más sobresalientes de la vida de Gabriela Paterito, ordenados de acuerdo a una serie de unidades de análisis, como son: la adaptación ecológica, la búsqueda y obtención de recursos, los valores y las relaciones sociales, y la mentalidad y el cambio social; en un esfuerzo de síntesis que tiene por finalidad ofrecer el bagaje de conocimiento sociocultural que explícita o implícitamente se desprende de su testimonio, dibujando episodios de su vida y la de su pueblo en un largo período que va desde mediados del siglo XX hasta la primera década del siglo XXI.

\section{ADAPTACIÓN ECOLÓGICA A LA VIDA EN LOS CANALES}

Uno de los primeros datos significativos que podemos apreciar en la biografía de Doña Gabriela es el rápido aprendizaje y el sentido práctico del mismo, en todos aquellos conocimientos que le serán útiles para la subsistencia en los canales. Nos informa cómo desde muy pequeña ya ayudaba permanentemente a sus mayores acarreando leña, agua, y cómo su madre la enseñaba a tejer cestos de junquillo, o ella misma aprendía observando por mera imitación de lo que veía en los demás. El ambiente patagónico y el modo de vida kawésqar no admite demora en el conocimiento de las técnicas de supervivencia en las que hay que adiestrarse desde temprana edad.

Estable tenía questá tejiendo cuando hay tiempo malo, cuando hay sol osioso, entonse a esa edá aprendí tejer canasto y ehpué me salía mariscar con mismo canasto cabía (que había) tejío yo misma sola, pero no e canasto como el que hacía mi mamá pero diferente, mal tejío, mal hecho, pero gual me mandaba, mobligaba que tenía que mariscar con eso; era mi trabajo mío nunca puede dejalobotao, ese era que me consejaba a mí: no hay que dejalobotao.

Palabras que nos recuerdan a las de Gusinde (1991 [1974]: 173), al decir:

[...] Así, la muchacha aprende de su madre los diversos manejos a los cuales está obligada cada día, ya sea dentro de la choza o fuera de ella; la actividad recolectora, el cuidado de los niños pequeños o las ocupaciones que la canoa exige sólo de ella; y, por último, todas las habilidades que le incumben, como la confección de cestitos, cosido de trozos de pieles y fabricación de adornos, entre otras.

Por otro lado, es igualmente apreciable la adaptación al ambiente físico que se desprende de los relatos, la capacidad para soportar las inclemencias meteorológicas (frío, lluvia, viento) o la falta de alimentos, el hambre cuando no encuentran nada que comer durante días, obligados a continuar la travesía con bebés incluso que cuidar. [...] ahora somo heliaco, [...] no puén ni mojarse [...], decía al comparar la manera de bucear que los hombres de ahora realizan con neopreno y aire comprimido, en relación a la que las mujeres de antes practicaban al desnudo y a pulmón:cholga tenía que busear, mi mamá, mi tía buseaba, que unas cuánta cholguita que saca no e tanto.[...] andaba a pata pelá [...] nos dice también para indicar lo raro que le resultó calzarse sus primeras botas después de haber caminado descalza durante 30 años. La adaptación física con mínimos 
recursos materiales a un ambiente extremadamente riguroso constituye un rasgo sorprendente entre los kawésqar del que lamentablemente existen pocas referencias etnográficas.

El dolor físico se presenta también en algunos episodios de su vida y los personajes que lo sufren aguantan estoicamente: ya sea el caso de su marido José Tonko que soporta sin apenas quejarse los fuertes dolores que, como lo describe, posiblemente fueran de vesícula, y sin embargo sigue remando, sin dejar de realizar sus tareas cotidianas. O ella misma, que pasa por alto los dolores del parto a los que dice no haber prestado mucha atención, afrontándolos con naturalidad allí donde rompiera aguas, a pesar de contar tan solo con la ayuda de alguna que otra persona que en ese momento la acompaña y por supuesto sin anestésico alguno. Fueron ocho hijos los que crió y algunos de ellos tuvieron que sufrir muy duras condiciones en los primeros años de vida.

Ese año nosotrocuidamo sola igual, poreso e que el parto yo no sufrí nunca, nunca me sufrí como otra mujere sufre pa tener su guagua; mora (demora) como tre, cuatro hora, no, yo no, nunca fue así, porque cuando anda esperando yo no comía tanto, nunca me cuidaba bien, sí trabajaba, sí, nunca me quedaba o me sentaba o me costaba, no, nunca me costao, porque finao mi tía me consejaba que haga ejercicio; [...]

La asistencia al parto por las mujeres, como confirma Alberto Achakaz (kawésqar ya fallecido) (en Vega 1995: 59), era en efecto la costumbre, aunque las circunstancias del momento con una vida marcada por el viaje no siempre lo aseguraban.

[Dice Achacaz] Cuando venía un parto (atalchachálap) la mujer era ayudada por su compañera. Se juntan todas las mujeres y la que entiende más es la que atiende. La rodean todas sus compañeras, que empiezan a apretarle el vientre (sarrakte) y iqué se yo! Hasta que sale la guagua. Después le echan un poco de agua y iya! El cordón umbilical (kikstal) lo cortaban con un cuchillo o cualquier cosa y lo amarraban. Después lo cosían, poniéndole un trapito caliente en la parte donde se cortó.

La incertidumbre que envuelve el modo de vida de sus coetáneos aparece como una constante a la que es preciso adaptarse. La navegación con tiempo en calma es con frecuencia sorpresivamente rota por una inesperada tempestad que les obliga a buscar un varadero de manera inmediata. La previsión de estancia en un campamento ha de ampliarse al ser imposible hacerse a la mar por las malas condiciones meteorológicas. La travesía de un punto a otro que con buena meteorología solía ocupar tres días, en condiciones adversas se podían demorar dos o tres semanas, ya que remar con una canoa monóxila en condiciones desfavorables supone un enorme riesgo, como bien saben. Es por ello que estar siempre alerta, preparados para afrontar cualquier tipo de adversidad, junto con la prudencia, son requisitos para lograr mayores probabilidades de sobrevivir en un ambiente tan incierto como el de los canales patagónicos. Ambos factores los observamos en numerosos episodios de la vida de Gabriela, que se acuerda bien dónde y con qué fuerza soplaba el viento cuando, llegando al punto de destino, tuvieron que improvisar un refugio donde permanecer varios días; o de las situaciones vividas por otros personajes próximos a ella como Zambrano (primo materno y fiel acompañante en buena parte de su vida), que optó por permanecer refugiado y a salvo junto con los hijos pequeños de Gabriela durante varios días en un lugar cercano a Guarello (isla perteneciente al archipiélago Madre de Dios), donde fue a cazar, mejor que arriesgarse a regresar con los menores y el mar en mal estado, a pesar de haber creado alarma entre la población que no cesó de buscarlos. En este caso resulta muy significativa la reacción tranquila de Zambrano, extrañándose del enfado que todos (mineros no kawésqar en su mayoría) mostraron contra él por no venir antes; sabía que si lo intentaba tal vez no lo lograría y mejor que tentar a la suerte decidió no correr riesgos innecesarios y proteger a los chicos de los que era responsable. Obró con prudencia, como buen experto que era, e hizo lo que debía, como asegura doña Gabriela.

[...] como e bote chiquitito no puee navegar por tiempo malo, viento fuerte, era chiquitito, moraron (demoraron) por mal tiempo, po no podía seguí, ese bote chico ademá con chico; así que por ese motivo fue que no se apuró, pescaron mal tiempo; claro, él no tenía culpa, está to listo, trajo harto huevo, quetro, to trajeron, no fue na de gusto tampoco, estuvieron bien, pasaron bien dijo los chico; nosotrosustao llorando, claro, no puee por meno, [...] 
Como prueba recurrente de prudencia está el hecho de buscar refugio cuando se navega, con tiempo suficiente a la caída del sol. Una continua lección desprendida del relato nos muestra que en un ambiente tan duro y contundente como éste, que deja tan poco margen de error, es preciso reaccionar rápido pero con mucha cautela; sobran las bravuconadas, osadías y heroicidades absurdas, siendo un terreno para extremar la prudencia. Es por ello que Gabriela se enoja con Iván Sanhuesa (director independiente de programas para la televisión), que desconociendo los canales patagónicos (no televisivos), insistía una y otra vez en acercarse al histórico lugar donde naufragó y se ahogó Lautaro Edén y la tripulación que lo acompañaba, ante su negativa de no hacerlo porque las condiciones lo desaconsejaba. Doña Gabriela contempló indicios que escapaban a la visión superficial del reportero - camarógrafo y aplicó un criterio, basado en el conocimiento intuitivo, al que solo a través de la experiencia continuada se puede llegar.

¡Bueno, vamo a ir ver éste, tiempo ehtá bueno! Yo le dije: ¿cómo sabe que tiempo ehtá bueno?, usted nunca jamá ha andaoconese el mar; si yo le digo questá malo, está malo, po. Mucha vesenasío, criaoenel mar, ¿cómo no voy a saber yo?, claro que me salí enojaoconel Iván Sanuhesa, canal 13 paree que era, [...]

La vida cotidiana que nos describe con mucho detalle está plagada de pautas que se ven alteradas a veces por los imponderables del momento. Las actividades habituales se sitúan en torno al mantenimiento del fuego, la obtención y preparación de alimentos, la búsqueda o construcción de refugio y abrigo, y el transporte por mar; técnicas todas ellas básicas para la supervivencia. Sin embargo, hay dos comportamientos que por su insistencia en el relato aparecen como constantes máximas y dan una idea de qué es lo que más preocupa u ocupa en mayor grado la atención de las personas, se trata de la espera o el deseo de que haya buen tiempo, traducido como tiempo calma; y la búsqueda permanente de alimentos, ya sean mariscos, mamíferos marinos o terrestres, aves, peces o bayas silvestres.

Salía buscar maucho, cholga, iriso cuando hay tiempo bueno calma, ya lo hasía sola to, [...]

[...] hay calma, así que dijo: yo voy a ir por lao norte, usted tenía que ir por lao sur; claro, $y$ así íbamo, mirando, y ehpué nosotros andamo por otro lao, allá donde encontraron nutria, [...]

[...] pa salir pa fuera, un tiempo de leste, calma la mar, gusto andar cuando está bonito así un día anda mar afuera.

[...] ahí quedamo, la mar calma estaba, finao mi hermano se fue buscar lobo, buscar siervo un estero parese que hay paentro, [...]

[...] aprovechá tiempo bueno y calma questá, si no ma rato va largá viento; claro, así fue.

[...] hasta lotro día seguimo, y manesió calma, tremeenda calma calor, había tiempo verano, andamo buscando lobito, llegamo la isla, ahí un campamento, siempre se deja lo campamento antiguo, [...]

Apreciamos preferencia por la estación veraniega, debido posiblemente, no solo a que la temperatura es más suave y hay muchas horas de luz solar, sino también a que es la época en la que cazan las crías de lobos marinos, se obtienen huevos de aves, y recolectan calafate y murtilla. Las 14 a 18 horas aproximadamente de luz solar que hay en primavera y verano hace que las actividades realizadas desde octubre hasta marzo sean más abundantes y variadas. Es también la época que recoge más narraciones de viaje, aunque estos están presentes durante todo el ciclo anual, sin que el invierno impida el cambio de residencia y la práctica nómada que le tocó vivir a doña Gabriela, la cual forma parte de su manera de ser. De hecho, aún sobrepasados los 70 años piensa y proyecta recorridos con chalupa para acampar a la antigua usanza. El viaje por los canales parece que queda impreso en la memoria y el carácter de quienes han estado expuestos permanentemente a él como medio de vida durante un tiempo prolongado.

Con Raúl cuánto viaje he hecho, hasimo, hasimo harto viaje con Raúl. Primer viaje que me sacó pacá, a ver, perate, Chacabuco, payápabajo, por canal Wai (White) porahi, porahi me llevó primera ve.

Yo he viajao harto; nosotroviajamo, y toavía estoy siendo viaje, sigo viajando, claro.

El cambio recurrente de residencia, aunque no se diga de manera explícita, posee un claro carácter ecológico, en la medida que permite no agotar los recursos del lugar de asentamiento, lo cual es básico para asegurar una existencia sostenible en el tiempo (ver Gusinde 1991 [1974]: 282-291; Legoupil 2000: 84; Piana \& Orquera 2004: 168); circunstancia 
que se ve algo amenazada por la llegada de loberos chilotes (ver Martinic 1999: 35-41, 2006: 1281; Bengoa 2004: 583; Aguilera 2007: 2), a los que hace referencia en varias ocasiones, aunque como problema social.

[...]que no haga tanto fuego porque puee venir algún chilote mañoso y te pueehasé alguna cosa,[...] al final hay puerto pero el puerto de chilote, dijo, son malo ahí.

Hasta antes de la llegada de las Fuerzas Armadas de Chile (FACH) a Puerto Edén, circunstancia que se dio en 1936 (posteriormente, en 1969 se crearía el poblado que lleva ese nombre, antes denominado Jetarkte-Kstal), es notable el aprovechamiento de los recursos naturales para distintos usos. En su narración describe numerosas escenas en tal sentido: cómo se construye una canoa monóxila de ciprés la manufactura de un balde con corteza de mañío para achicar agua; la preparación de la ruca y del lecho de ramas para dormir dentro de ella; conocimientos y prácticas que constituyen una prueba más de adaptación y autosubsistencia, las cuales se ven alteradas con la introducción de materiales y costumbres foráneas que desplazan progresivamente a las propias del lugar, como también es apreciable en el relato: el rancho sustituyó a la ruca, el colchón de lana al lecho de ramas, la chalupa a la canoa, etc.

[...] porque cuando la lana se usa mucho la cama quea duro, queapelotonao, entonse ese tiene que lávalo, y ehpué sécalo y estendelo bien, y volvéllená de nuevo otra ve el colchón, [...]

Todo ello supone que para entender la evolución del modo de vida kawésqar, al menos en el último siglo, es imprescindible aplicar una doble perspectiva: la ecológica y la del choque cultural, como bien supo ver Emperaire (1963: 154-155) en el mismo Puerto Edén medio siglo atrás.

Todos ellos se sienten aún más movidos a partir desde que la vida en los campamentos no es ya lo que era en otro tiempo. Han desaparecido las fiestas y ceremonias. Ya no se usan las pinturas corporales, no hay ya sino muy raras veces cantos y mímicas. El interés de los miembros del grupo se desvía de lo que constituía en otro tiempo la vida misma de la tribu para gravitar únicamente en torno de los loberos y sus bienes tan deseables. Muchos niños mueren. Los adultos son afectados por un mal desconocido. Poco a poco, una especie de desaliento y de resignación se apodera de los alacalufes [...] Los pasajeros y las tripulaciones, llenos de piedad por los desgraciados indios, desnudos al viento y bajo la lluvia, se pusieron a distribuirles de todo un poco, utilizable o no. Los indios empezaron a habituarse a recibir por el solo hecho de pedir. La caza y la pesca, que eran, sin embargo, las actividades vitales del grupo, pasaron a un segundo plano, pues eran menos remunerativas y mucho más penosas que la espera del paso de los barcos.

Por otro lado, como medida del tiempo, dentro del ciclo anual resulta muy significativo observar las consecuencias económicas que traen consigo los cambios en la naturaleza. Para distinguir la llegada de la primavera no habla del aumento de las horas de sol sino de la puesta de huevos de ciertas aves y su captura para el consumo, lo cual ocurre en torno al mes de septiembre; así como el verano es tiempo para la recolección de bayas silvestres (calafate, murtilla), entre diciembre y enero; y la parición y captura de popis (del inglés puppies), las crías de los lobos marinos, en febrero. El sentido práctico, sobre todo orientado a las cosas de comer, está siempre presente y es lo que marca el transcurrir del tiempo. Aunque sea en otra escala, también el paso de los buques que circulan regularmente en la actualidad entre Puerto Montt y Puerto Natales, constituyen una medida del tiempo, semanal en este caso, que queda significado ante todo por la posibilidad de hacer trueque o tcas (práctica de relación social ampliamente documentada cuyas implicaciones van más allá de lo económico), como ya señala Emperaire (1963: 156), vender artesanía o algunos sacos de cholgas o almejas, para poder comprar víveres (harina, arroz, azúcar, pasta, etc.); así como también para viajar y salir por algún tiempo de los canales sin necesidad de remar.

[.. .] ante llegaba estable el buque acá; tenía fruta, tenía galleta, tenía too acá, y como un día llegó un buque argentino, to lo buque argentino llegaba nante acá; buque argentino, buque peruano, to eso, chino, japoné, ahora no estable.

[...] vamopasácrusá, ese buque pueetirá alguna cosa; claro estaría como do hora ahí, y nosotroveníamo abajo resién saliendo langostura, y cansamollegá a buque, iba saliendo un rato ya. ¡Chuta!, cuando llegamo ya empesaron dar cosa: bajó aseite, fruta, una cajita desa cuestión de caramelo, dos cajita, sistuvieramá cuántas cosa 
má iba a dar, [...]

Desde la cultura kawésqar se espera algún regalo de quien llega de visita (tčas), aunque visto desde fuera haya sido entendido numerosas veces como una práctica pedigüeña ampliamente referida en la literatura desde los primeros contactos con los navegantes del siglo XVI (Fray García Jofre de Loaysa en 1526, Ladrillero y Cortés Hojea en 1557-1558) y sucesivos encuentros posteriores (Antonio de Córdova en 1786, Fitz-Roy en 1826 y 1832); prácticas atendidas como obras de caridad a personas calificadas con desprecio. En esa línea Pedro Nolasco en 1897 (cfr. Vega \& Grendi 2002: 89) dice de ellos:

[los alacalufes] se acerca a los buques para hacer su triste y miserable comercio o para pedir ropa o galletas que siempre le dan en abundancia, no son adictos a la bebida pero algunos suelen recibir aguardiente $u$ otra clase de licor. Su aspecto es repulsivo. Son feos.

Vivir en un ambiente muy marcado por los extremos: entre la calma y la tempestad, hace que el cuerpo y el carácter se endurezcan para hacer frente a los rigores del clima; pero al mismo tiempo cobra una especial sensibilidad con la que apreciar la belleza que encierra su mundo, cuando el viento, la lluvia o el frío amaina y deja disfrutar a los sentidos. Las muestras de valor, entereza y determinación ante la adversidad que manifiesta la actitud y el comportamiento de doña Gabriela y los que la acompañan en muchos de los momentos relatados (marido, hijos, hermana, cuñado, primos, compañeros y compañeras de viaje), se complementa con una elevada sensibilidad para apreciar y aprovechar los buenos momentos de tiempo en calma, sobre todo allí donde son más escasos, como ocurre en torno a Guarello dentro del archipiélago Madre de Dios, como nos comenta.

En verano, por este tiempo, igual es bonito porahi, bonito lugar salíamo a recorrer porotro lao; andamo un día entero, si no íbamolojar por otro parte, y así andábamo.

[...] Amanesiólotro día tiempo bueeno, viento igual que como este viento (brisa moderada), de gusto navegar conesa la vela, llegamopa bajo a la mitá, tempraano, temprano teníamo que ser carpa.

\section{BÚSQUEDA Y OBTENCIÓN DE RECURSOS}

La mayor parte de los comportamientos descritos tienen un carácter económico, ofreciéndonos una precisa información sobre las formas empleadas en todo aquello que forma parte de la cultura material, así como del uso y sentido que se desprende de cada una de ellas.

De entre todas, la cuestión alimenticia ocupa sin duda el papel dominante por la cantidad de datos que nos ofrece, sobre todo en lo que respecta a su obtención. Aunque, los momentos de hambruna no están ausentes y sin perder la calma se veían resignados a aguantar hasta que pasara el temporal o encontrar un lugar más próspero. Circunstancia que también refiere Emperaire (1963: 132-133):

Toda hora es buena para comer. [...] Si el día debe pasarse en la inacción y la alimentación es suficiente, el tiempo se divide entre comer $y$ dormir, en la propia choza o de visita en las chozas vecinas. [...] Así como es capaz de absorber una enorme cantidad de alimento, con una capacidad que parece ilimitada, así también el indio alacalufe es capaz de resistir al hambre cuando circunstancias como el mal tiempo le imponen un ayuno forzado.

De acuerdo a su relato, podemos entender que la base alimenticia kawésqar se sostiene en el marisqueo, complementado con la carne y grasa de lobo marino. La primera alternativa constituyó el recurso más fácil y eficiente por la cantidad de cholgas, choros, almejas o erizos, existentes; actividad convertida en la constante diaria. Y la segunda cubría las necesidades dietéticas de materia grasa, imprescindible para soportar los rigores del clima. El resto de actividades destinadas a la obtención de alimentos aparecen como estacionales o esporádicas: recolección de bayas, empleo de trampas para aves, recogida de huevos, caza de huemul.

[...] anda traendo su maucho, su cholga, con su canasto que hise, conesa misma, y ese cuando tiene má cholga, má marisco, mejor toavía para ello, entonse otro si falta ella lo repartía, así vivía ello;

[...] y ello comía to lo día marisco, puro marisco, armeja y cholga.

Entre los procedimientos empleados llama la atención la resistencia al frío que es preciso desarrollar para la captura de cholgas por inmersión a pulmón, como cuenta que hacía la madre de Raúl (su actual compañero o marido) en su juventud; 
la intuición que tienen para encontrar los nidos de aves y aprovechar los huevos; la habilidad y destreza mostrada en la caza al acecho del pato quetro con lazo o el pato lile, en la que su amigo y primo Zambrano era tan diestro; el dominio de la ocasión en la caza nocturna con antorcha de los cormoranes; la estrategia diseñada y la connivencia de los perros para capturar ciervos por persecución; la astucia para capturar peces mediante la técnica de corral en las pequeñas ensenadas; la decisión y sangre fría para golpear a los popis; y la valentía para enfrentarse al lobo de mar; hechos todos ellos relatados que coinciden con lo que contaba el viejo Alberto Achakaz (en Vega 1995: 40) y podemos leer también en Emperaire (1963: 178-192). Los recursos son variados y no todos los personajes que aparecen en escena demuestran tener las mismas cualidades y grado de eficacia en el ejercicio de la tarea; aunque la suerte y la oportunidad juegan también un papel importante para obtener éxito.

[...] y ahí salía recorrer otro estero más padentro, fuímo a buscar lobo, hay lobería que hay, parisión; ahí sacaron lobito nuevo pero no había tanto, poquito no má;

Finao mi hermano cortó un palo pa que yo vaiga a casar, po; él andaba traendo arpón, arpón lo andaba traendopa casar lobo grande; yo me fui con palito má chico pa choiquear.

El aprovechamiento de las ballenas varadas no parece que se diera con harta frecuencia. Tan solo lo cita en una ocasión en el canal Concepción, aunque cuando ocurre son muchas las familias que acuden al lugar para abastecerse de carne y grasa durante bastantes días; los huesos que finalmente queden al descubierto servirán también para la manufactura de puntas de arpón.

[...] pa fuera pa Ladrillero ese ehtabavarao de ballena ahí, lleno lleno, no sé por qué ese año harto, harto ballena, ya no lo vimomáehpué.

Además de una actividad económica se trataba de un acontecimiento propicio para el encuentro y la interacción social, como recoge Manzo (2002: 152).

En ocasiones, diferentes familias se congregaban en grupos con el fin de acercarse a un lugar donde había varado una ballena. Este suceso era informado a los demás mediante señales de humo, método que también utilizaron para reunirse en torno a naufragios, de los cuales obtenían alimentos y materiales para hacer instrumentos.

En efecto, como si fueran ballenas varadas, el saqueo a los buques accidentados y abandonados era práctica común siempre que había ocasión, lo cual era celebrado por quienes participaban en el botín.

Por ese tiempo había un buque varao ahí que se llama Cachimpual, la gente ehtuvieron ahí, un muellesitopa sacar alguna cosa ahí,

[...] ese fue madera del buque, conesehisimo ranchito [...]

[...] varó un buque cargao de asúcar y cualquiera puee llegar y sacar.

Por otro lado, es significativa la actitud dubitativa que Gabriela, junto con Esther (mujer kawésqar, amiga de la infancia) muestran en su juventud, al participar por primera vez en la caza de popis a garrotazos. Al sentimiento inicial de lástima por tener que golpear con un palo en la cabeza a las indefensas crías de lobos marinos, posteriormente se le une un componente divertido que provoca risas cuando por la falta de práctica se golpean ellas mismas en las piernas al no acertar algunos golpes en la presa, convirtiéndose lo que en principio era un drama en una situación al mismo tiempo lúdica que la hacía más llevadera.

Cuánto no reíamodehpué, ninguno los do, pero lotro día que será me dolía mi cuerpo, mi canilla to esa pierna, tomachucao, asuleao, claro, onde pegaba con mismo palo pa matar lobo pero nunca llegaba pa matar ensima lobo.

Los hombres acostumbrados a ello actúan con determinación y rapidez para aprovechar la sorpresa y matar el mayor número de animales, no caben sentimentalismos y actitudes piadosas por tratarse de crías; en situación de supervivencia cualquier procedimiento y cualquier víctima es válida para asegurarse el sustento, responde a un instinto básico que solo puesto en situación y desde dentro llega a ser del todo entendible.

[...] suerte fueron a buscar lobo a fuera, una piedra que hay, trajeron cualquier cantidá de lobo nuevo, ese era lalimento que teníamo.

En lo que respecta a la preparación de alimentos, llaman la atención varios aspectos: la dependencia del fuego, la práctica de asado y la no conservación. Invariablemente las comidas que cita en el relato son pasadas por el fuego; aunque sabemos que de vez en cuando alguna que otra almeja o incluso cholga o choro se comía cruda; 
por lo regular, a excepción de los erizos y las bayas silvestres, se cocina todo, y la manera habitual de hacerlo es asado, exponiendo directamente al fuego las piezas que se vayan a comer, ya sean mariscos, o carne de mamíferos o de aves; el uso de recipientes para cocer es fruto de los préstamos culturales con quienes vinieron de fuera. Salvo los pocos alimentos que ingieren crudos, todo se asaba antes y además de manera bastante inmediata tras la captura. Las reservas eran mínimas, los mariscos no se conservaban por más de dos o tres días, aunque, como nos comenta de las mujeres antiguas, ellas eran más previsoras y siempre contaban con alguna reserva de alimento, especialmente durante las largas travesías, para salir de algún apuro imprevisto; las personas con las que convivió en su juventud eran menos previsoras que las antiguas, nos decía.

[...] nosotro un rato que lo llenamo marisco ya en la tarde ya no teníamo, pero la persona antigua no, po, ya tiene diferente su relación, lo reserva.

Es tras el contacto con los chilotes cuando se empieza a practicar el secado de algunos alimentos, especialmente cholgas, aunque con una finalidad comercial. Con la harta presencia del humo en el interior de la ruca, circunstancia muy comentada en la literatura (Emperaire 1963:255; Gusinde 1991 [1974]:179; Lausic, 1993:28; Vega 1995:18) y también citada en este relato, con los problemas derivados en los ojos, resulta curioso cómo no lo empleaban para ahumar alimentos de autoconsumo y así conservarlos durante semanas y aún meses, habida cuenta de que, aunque los recursos eran habitualmente abundantes, al menos en marisco, no están ausentes los lugares y momentos en donde se pasó hambre, bien porque el sitio no daba de sí o porque el mal tiempo impedía salir.

[...] ahí pasamo un hambre, porque porahienese lugar no hay marisco, no hay maucho, no hay chorito, el lugar e feo, pasamo mal rato, total que no había qué comer, pasamo hambre, tiempo invierno, y mala marea, la marea no bajaba nada, ni una cosa, obligao aguantarse así.

En cualquier caso, el fuego ocupa un papel crucial para la supervivencia en los canales y así se desprende del relato, al aparecer como constante en la vida cotidiana: fósforo sí que no poíafatar, ese e único e máprincipá, decía. Fuego obtenido por medio de fósforos, no por el procedimiento antiguo de percusión de piedras (cuarzo y pirita), como se cita en la literatura (Emperaire 1963:121), que en ningún momento menciona. De este necesario recurso, lo que más llama la atención es su mantenimiento y presencia continuada allá donde anduvieran, ya fuera en el interior de la ruca, del rancho o también, aunque no siempre, dentro de la canoa durante una travesía. Insiste en que no podía faltar debido a sus muchos e importantes usos; empleado principalmente para calentar y cocinar, pero también para alumbrar, así como para la preparación de madera y construcción de canoas.

[...]no sé cómo lo hiso fuego, porque ehtaba lloviendo; teníamo fósforo, ese e má principal, teníamo fuego.

Sin fuego resulta difícilmente imaginable la vida humana en los canales, constituye un recurso imprescindible para la supervivencia, como bien apunta Doña Gabriela, y realmente la única manera que tenían en el pasado para entrar en calor, secarse y bajar la humedad relativa dentro de la vivienda, en un ambiente con temperaturas que bajan de $0^{\circ} \mathrm{C}$ durante el invierno y vientos que disminuyen la sensación térmica, con precipitaciones que sobrepasan los $4.000 \mathrm{~mm}$. anuales, y una humedad relativa del $80 \%$ (Emperaire 1963:49-53; Zamora \& Santana 1979: 111-143; Transcorp 2002:15-19; Martinic 2004: 15-16). No por casualidad una tarea permanente, al tiempo que obligación por parte de algún miembro de la familia, es cortar y acarrear leña con la que hacer fuego para preparar los alimentos, entrar en calor y evitar enfermar. De su infancia nos contaba:

[...] cuando terminaba mariscar tengo que buscar un leña, pero leña gruesa no, una chamisa que le dise, entonse tengo que buscá un viaje de leña, esa chamisitapa hacer fuego, patisar (para atizar) fuego, to esa cosa, iba buscalo y lo traía y así iba costumbrando a trabajar uno.

[...] dejamo harta leña pa que venga hacer fuego a la tarde.

Otra de las constantes y medio esencial de subsistencia es el transporte a través de distintas embarcaciones. La ingeniosa y socorrida canoa de corteza queda ya en el recuerdo a través de las referencias históricas (Ladrillero 1557-1558 y Fitz-Roy 1826-1832, cfr. Cárdenas et al. 1993: 62, 74; Sarmiento de Gamboa 1579-80, Lucas Bridges 1886, cfr. Lausic 1993:17-21; Antonio de Córdoba 1787, cfr. Gusinde 1991 [1974]:623; Lautaro Navarro 1894, cfr. Vega \& Grendi 2002: 
37) y descripciones de algunos autores (Coiazzi 1914: 110-111; Emperaire 1963: 166-177; Gusinde 1951: 198-200, 1991 [1974]: 232-243, 1986: 423-441; Barros \& Armstrong 1975: 40; Goiri 1997: 14-27; Chapman 2003: 6-32; Vairo 2007 [1995]). Doña Gabriela alcanzó a navegar en canoa monóxila de coigüe en donde fácilmente viajaban cuatro o cinco personas, una familia completa más o menos numerosa. Canoas a remo a las que en ocasiones se improvisaba una vela para aprovechar la fuerza del viento, aunque también aumentaba notablemente su inestabilidad.

Ehtuvimohasiendo canoa para arreo pafuera, porel canal Machao que dise ahí, porahí hiso canoa, to hiso canoa nueva, los viejo lo dejaron ahí, lúnico monte alto que hay, de palo grande tenía que ser, [...] Canoa de coigüe. Así que to eso hiso canoa, lo tre canoa nueva, cuanto tiempo, un mé tenía que ehtáhasiendo canoa ahí, sin vívere, sin na.

[...] cuando llegabamo o la otra canoa premero llegaba, dehpué llegaba ello y ehpué do má y así se juntaba, pero nunca andaba to junto

[...] andaba finao mi tío, do, tre canoa paree que era; claro, tre canoa, y salieron viaje largo y llegamo; andaríamo como tre, cuatro mese, en reor, poracá fuera,

Fue la canoa el medio de transporte utilizado durante su infancia y juventud para posteriormente pasar a la chalupa, embarcación más estable y de mayor capacidad, que algunos kawésqar aprendieron también a fabricar, caso de Francisco Arroyo, actual vecino y cuñado (marido de su hermana, ya fallecida).

De uno u otro modo, la embarcación familiar es presentada como el elemento esencial para desplazarse en un escenario de canales y archipiélagos en donde tan solo se hace vida donde permite la zona de costa, ya que tierra adentro el denso y duro bosque magallánico, o la movediza turba, hace difícil la penetración y la vida en el interior. Dificultades ambientales que no parece hayan cambiado en los últimos siglos y que ya fueron percibidas y descritas por Sarmiento de Gamboa en 1579 (cfr. Aguilera 2007).

La masa de tierra, lo que vimos, no nos pareció bien, cerca de la mar; porque no hay migajón de terrial, sino de la demasiada humidad, hay sobre las peñas un moho tan grueso y corpulento que es bastante criar en sí y sustentar los árboles que se crían en aquellas montañas; y estos céspedes deste moho es esponjoso, que pisando sobre él se hunde pie y pierna, y algunas el hombre hasta la cinta; y hombre hubo que se hundió hasta los brazos, y por esta causa son trabajosísimas de andar estas montañas; y también por ser espesísimas, tanto que algunas veces nos era forzoso caminar por las puntas y copas de los árboles, y podíannos sustentar por estar los unos árboles con los otros fuertemente trabados y entretejidos, y teníamos esto por menos trabajoso que andar por el suelo, y cualquiera destos caminos era mortal, lo cual hacíamos por excusar despeñaderos.

El espacio vital por donde Gabriela se ha desenvuelto durante setenta años abarca un área que va desde el faro de San Pedro, en la zona norte de la isla Wellington hasta la isla de Guarello en el archipiélago Madre de Dios, teniendo el área donde en la actualidad se sitúa Puerto Edén como lugar más transitado. Concretamente el asentamiento base de muchas familias kawésqar estaba en Jetarkte-kstal (frente a la actual villa de Puerto Edén); lugar cargado de historia, una historia marcada por el encuentro entre familias nativas, a la vez que escenario elegido por el Estado chileno para desarrollar un sistemático y progresivo proceso de asimilación cultural. Los viajes desde Jetarkte-kstal primero, y luego Puerto Edén, hasta Guarello, y viceversa, son los más mencionados y el área por donde más tiempo anduvo; viajes cargados de aventura por la incertidumbre y los imponderables a los que normalmente había que hacer frente, como se desprende de uno de ellos:

[...] iqué sufrimiento má grande!, a la mitá canal; onde que vamo estaba lejo, por lo do lao, un golfo que hay, ¿ahora qué hasemo?, y Raúl me dijo: ehtate tranquila, alguna forma vamo llegar. Claro, él empesó remar solo, a los do remo, yo sentá a popa, y ya que largaba llorar a puro miedo, no había qué haser; jchuta!, le dije ¿ahora qué hasemo?, si un caso que llegamo a tierra ¿con qué vamo tapar?

Por el particular testimonio de Gabriela y las conversaciones mantenidas con los kawésqar de mayor edad, no parece que se lo pensaran mucho para emprender el viaje: ante la iniciativa de alguien que proponía ir a Guarello (desde Puerto Edén) apreciamos una predisposición en las personas al aceptar sin dudarlo, como si lo estuvieran deseando o esperando. Travesía que duraba aproximadamente una semana a remo, con buenas condiciones de 
norte a sur, y algunos días más de sur a norte (de Guarello a Puerto Edén). Viaje que se facilitó mucho con el empleo del motor fuera borda, reduciéndose a apenas dos días, aunque también se encareció y condicionó a la obtención de la gasolina suficiente.

$\mathrm{Al}$ igual que observamos cambios notables en el uso de embarcaciones (de la canoa monóxila a la chalupa a remos y de ahí al empleo del motor fuera borda), es apreciable también el cambio en la construcción u obtención y uso de la vivienda. Hasta la llegada de las FACH a lo que ahora es Puerto Edén, los kawésqar del lugar vivían en rucas o carpas, refugio hecho con ramas, de forma abovedada $y$ planta circular, de unos $2 \mathrm{~m}$ de diámetro y $2 \mathrm{~m}$ de altura por el centro, en donde se protegían de las inclemencias meteorológicas, dormían y hacían vida mientras persistía el mal tiempo. Muchos eran los lugares donde había refugios de esas características, con más o menos capacidad, que eran usados de manera provisional por toda familia que lo necesitara a su paso. De hecho, buena parte de los viajes lo hacían por etapas, pernoctando en aquellos puntos donde había rucas, o más bien el armazón de la ruca, que cubrían con las pieles o plásticos que cada familia llevaba a bordo. La norma era y es que toda ruca deshabitada y abandonada podía ser usada por cualquiera que tuviera necesidad de ello, lo que nos informa de un sistema habitacional práctico y solidario del que todos se aprovechan y de una mentalidad muy poco posesiva y dada a compartir.

[...] ahí hisimo carpa, campamento viejo siempre hay vara, siempre lo deja antiguamente, siempre lo dejaba vara porque nunca lo sacaba; entonse cuando viene otra gente ahí tenía que quedarse, porque sin vara no podía hacer na, tenía que salir pal monte; la vara e lo má principal, cuando no haya vara enese campamento tiene que salir buscá pal monte, dehpué esa vara tiene que dejalo así como questuvo, como que lo hisieron.

El rancho construido con madera, plástico y demás materiales de desecho, desplazaría a la ruca, como se desprende del relato. El contacto con los aviadores, con los chilotes o con los mineros de Guarello, dan lugar a este cambio en la vivienda, que pasa a tener la planta y paredes cuadradas o rectangulares, el techo plano con o sin inclinación, y mayor capacidad en su interior. Vivienda que marcaba un cambio significativo, y al mismo tiempo, imaginamos que visto desde fuera, daría la impresión de ser una entrada en la modernidad por la puerta de atrás, integrados en la cultura de la pobreza por el aspecto y procedencia de los materiales de desperdicio con los que estaban construidas.

[...] ahí lo botaba el saco, y el viento, el mar lo tiraba pa tierra, porahí la playa estaba lleeno saco deso; conese lo tenía tapao su rancho, su carpa,

[...] rancho era que teníamo, teníamo tremendo rancho porque calamina es viejo, usao, sacan, rompen, cambian nuevo la casa y hay basural, ehtámontonao esa playa y entonse José (su primer marido fallecido) lo garró, lo trajo, hiso un rancho,

Sería la imagen de indigencia que ofrecían los ranchos el motivo por el que el Estado, a través de la Intendencia de Magallanes, regaló las primeras casas a la población kawésqar de Puerto Edén, circunstancia en la que doña Gabriela fue, de manera inesperada y sin proponérselo, la persona responsable al hacerse eco de la situación de su gente ante las autoridades en Punta Arenas.

[...] llegaron como ocho casa, pato, no panosotro no má, pato cuánta persona que hay, sí, sí.

El traslado a la casa prefabricada constituye un paso más en la integración y asimilación al modo de vida chileno, proceso que apreciamos con toda claridad en el relato al corresponderse con un mayor grado de interacción con la población foránea, y el aprendizaje progresivo del castellano. La casa donde actualmente reside Gabriela y desde donde nos contó su vida, aunque algo deteriorada por el paso del tiempo, dispone de luz y agua corriente, además de fogón de leña y algunos electrodomésticos, cama, sillas, mesas, sofá y diversos objetos y utensilios; compartimentada en tres espacios: salón-comedor, dormitorio y cuarto de baño, dista mucho de la antigua ruca y marca un nuevo estilo de vida. Una radio-emisora (sistema de comunicaciones radiales) instalada en su interior la mantiene informada permanentemente de lo que ocurre en torno a la villa, sobre todo en cuanto al tráfico marítimo, sin necesidad de salir fuera, son otros tiempos.

En sus palabras podemos apreciar también la división de papeles en razón del género, aunque su versión no coincide exactamente con lo dicho por Emperaire (1963). Generalmente y según su testimonio, hombre y mujer mantenían una actividad 
complementaria en el ámbito familiar sin que ninguna tarea fuera tabú para el otro sexo. De esa manera intercambiaban las labores si era preciso y, sobre todo, en caso de ausencia del consorte, quien quedara sola o con sus hijos tenía que hacer todo lo que hiciera falta: cortar y acarrear leña, alimentar y mantener el fuego, mariscar, navegar, etc.

[...] yo salía trabajar, salía buscar leña, hachaba, carreaba leña, alumbraba, to eso yo lo hasíato,

Durante las travesías por mar, en su caso concreto era el hombre quien generalmente remaba, aunque bien es cierto que haber criado ocho hijos la mantuvo ocupada mucho tiempo en labores que le impedían tomar los remos, como claramente expresa en más de una ocasión.

[...] la Esther y yo no podíamo remar porque teníamo guagua, así que no.

[...] yo no podía remar porque tenía questar cuidando la guagua.

La provisión de alimentos era una tarea compartida. Generalmente del marisqueo por el litoral se ocupaba más la mujer y el hombre de los distintos tipos de caza, ya fuera destinada a mamíferos o aves; en la pesca mediante corral participaban ambos. La preparación y consumo de alimentos cuando navegaban de un lado para otro cada cual lo hacía de modo individual; una y otro asaban directamente en el fuego central de la ruca las cholgas o productos que se fueran a comer, hasta hartarse.

Los niños y niñas, pese a las dificultades que sufrían, no dejaban de tener una vida lúdica, por lo que Gabriela nos cuenta de su infancia y la de sus hijos. Jugaban, se divertían, peleaban, como es propio de la edad, pero igualmente ayudaban a sus mayores con los encargos que le hacían: acarrear leña o agua, cuidar a sus hermanos, atender al bebé, etc., por lo que desde temprana edad adquieren responsabilidades de las que han de dar cuenta, siendo obedientes y disciplinados. La protagonista de esta historia, no obstante, muestra desde el principio su rebeldía y se resiste a aceptar todo aquello que no le gusta: le responde y protesta a su padrastro; ya huérfana huye a tiempo para no ser dada en adopción (o vendida, según se entienda) sin su consentimiento; vivencias todas ellas que le fueron forjando un carácter fuerte.

[...] los perro me sustó y merranqué para el monte otra vé [rompe a reír abiertamente], ese nunca lo contao eso, y ahí siguí caminando málejo, parece que había llegao ahí namá, de gusto igual, a la fuerza no me iba llevar, po.

La vida autosuficiente que llevaba en los canales durante parte de su infancia y juventud en compañía de las personas con las que le tocaba ir, se torna cada vez más dependiente de los agentes externos, que van de paso o se instalan allí. En tal sentido, el tránsito constante de buques motivaba acercarse a él para recibir regalos o hacer trueque: pieles de nutria, artesanía o marisco, por víveres, ropa o dinero. La búsqueda de víveres se convierte casi en una obsesión; para hacer una larga travesía o incursiones de caza por varios días era imprescindible abastecerse de víveres, es decir: harina, azúcar, pasta, arroz, etc., con lo que mantenerse; ya la cholga o la carne de caza no llena lo suficiente. Costumbre que se adquiere y consolida fundamentalmente a partir de que las FACH institucionalizaran el abastecimiento periódico y gratuito de víveres a la población kawésqar asentada frente a lo que hoy es Puerto Edén. Acto caritativo del Estado que, como aprecian también diversos autores (Emperaire 1963; Gusinde 1991 [1974]; Martinic 2004), trajo en consecuencia no sólo la dependencia de productos traídos del exterior, sino el abandono de la vida nómada, la pérdida de ganas de trabajar y la adquisición de hábitos nocivos como la ingestión abusiva de alcohol.

Trajo ropa, frasá, y pa lo niño trajeron traje de colegio, ropa, sapato, to trajeron y esa gente de chilote llegaron igual, criendo quera cosa que comandante lo traía de la FACH,

[...] P... igual ante buseaba, bueno conese alcohol ya no lo dejó trabajar ese.

No pasa desapercibido la aparición y uso de la artesanía, como recurso para obtener beneficio económico. Los canastos de junquillo que en lo cotidiano usaban para meter las cholgas, es reducido en su tamaño y vendido por dinero o intercambiado por ropa, tetera, fruta o harina, al igual que las canoas de corteza en miniatura, que, como nos diría en alguna ocasión, la aprendió de los yaganes, que la idearon primero. Algunos hombres hicieron valer también las puntas de arpón, además de como arma arrojadiza contra lobos marinos, como pieza artesanal orientada al mercado. Tecnología convertida en artesanía con la incorporación de nuevos usos y sentidos en consonancia con una época diferente en donde lo que en el pasado solo 
tenía valor práctico, como eficaz herramienta de subsistencia, ahora lo tenía como mercancía con la que comerciar.

Yo allá a Guarelohasía canasto, canasto de junquillo lo cambiaba por cosa, o que sea yo mandaba buscar mi ropa, mi sapato o tetera que me hasía falta, el cambio lo hasía yo, nunca cobraba plata porque no lo conosía, así vivíamo ante.

El trueque que nos presenta como única manera de transacción económica utilizada por los kawésqar cuando ella era niña, se altera notablemente con la introducción del dinero en papel moneda como medio de cambio, para la compraventa de mercancías, así como para el pago de servicios.

Pero ehpué, a poco a poco íbamo prendiendo, y ehpuéyanpesé prender un poco, yampesé tener plata; ya ese tempo, plata era escudo, no sé cuánto escudo habría vendido, éste, compraba ese canasto y bote; entonse, ahí poco estaba conosiendo, cambiando uno, así andaba a Guarelo.

[...] ahora que llega turista que compra artesanía, uno solo ya hase su platita, seguro, cuando tiene ya compra cosa que falta.

El dinero, los antiguos escudos que luego se transformarían en pesos, dicho con cierto asombro, sería lo que empezó a obtener como recompensa de su labor artesanal; dinero que a su vez le serviría para sacar (comprar) víveres de la ECA (Empresa de Comercio Agrícola) y posteriormente de EMAZA (Empresa de Abastecimiento de Zonas Aisladas) que sustituyó a la primera y tanto se mencionan en su relato al contar con almacenes en Puerto Edén; almacenes de víveres y utensilios que constituían una gran despensa a la que acudir, aunque con dinero, y rompía definitivamente con la autosubsistencia, el vivir sin reservas, y el nomadismo que había caracterizado a los kawésqar que transitaban por esos lugares algunos años atrás.

Por otro lado y ligado también con lo económico, hay que hacer mención de las consecuencias que trajo consigo otro gran factor venido de fuera como fue el trabajo asalariado. En principio, los empleos de su primer marido, José Tonko, la llevó a determinados lugares: a Guarello primero por la tala de madera y luego el trabajo en la mina; y más tarde a Puerto Edén. Trabajo asalariado que en muchos casos, sobre todo durante la estancia en Puerto Edén, no le veía rendimiento, reprocha una y otra vez, viéndose obligada a buscar empleo ella misma y por último a producir artesanía para obtener recursos y sacar así adelante sus ocho hijos.

[...] yo me he trabajaoto mi vida, empecé trabajar joven, toavía sigo trabajando.

El trabajo asalariado y especialmente el realizado por encargo, concretamente el de la cholga seca, lleva consigo con toda claridad el sello de la explotación. Al margen del empleo de minero que su marido José Tonko ejerció en Guarello, del que no conocemos el salario que recibía, pero del que no se aprecian quejas y sí satisfacción general durante los períodos de estancia allí, el relato de doña Gabriela está plagado de situaciones de abusos laborales, sufridas tanto por ella misma como por las personas cercanas que le rodeaban. Es significativo, por ejemplo, el hecho de que el jefe de los almacenes de víveres y utensilios en Puerto Edén la menospreciara no pagándole nada por haberle lavado la ropa, aunque de nuevo surge en su persona ese punto de rebeldía que la mantiene alerta para que no vuelva a suceder.

[...] un día me mandó lavar ropa el jefe de la fábrica, [...] do docena de ropa: sábana, pantalone, son grande, ese tiempo yo lavaba la tina, [...] así dijo que te iba a pagar; ya, dije, mañana lo voy a tener listo, hoy mismo voy a lavar al tiro; [...] ¿tu cree que me pagó?, no, nada. Y ehpué yo me queé rabia, dije: pobre que me lo mande otra ve la ropa lo voy hacer peaso, le dije, [...] ¿cómo voy estar lavando grati?, le dije yo; a mí me cuesta jabón, le dije yo, [...] así que, y ahí nunca má.

Rebeldía que no se aprecia, de acuerdo con lo dicho, en la actitud resignada de su primer marido, José Tonko, al no recibir remuneración alguna tras meses de trabajo en la tala de madera, igual que le ocurrió al bueno de su primo Zambrano. Pero aparte de esos hechos puntuales, el trabajo en la cholga seca constituye un caso de explotación sistemática del que son víctimas tanto kawésqar como chilotes. Siendo una tecnología introducida por estos últimos, en el relato podemos observar tan solo la punta del iceberg de lo que constituye un sistema económico marcado por la usura. Sistema en el que tres o cuatro personas se aíslan en el lugar elegido para trabajar sin descanso durante algo más de un mes, sufriendo las inclemencias meteorológicas, el agua fría y el humo en los ojos, para finalmente no recibir prácticamente nada en compensación o unos pocos pesos, dado 
que el dinero que obtienen por la venta de la cholga seca se equipara aproximadamente con el precio de los víveres que necesitan para trabajar y para que viva su familia durante ese tiempo. Curiosamente la misma persona que habilita y vende los víveres a los trabajadores a precio de mercado, les compra la cholga para revenderla posteriormente duplicando o triplicando su valor inicial. Y más curioso resulta todavía que la persona habilitadora que posee el monopolio de la compra y venta de cholga seca en Puerto Edén, sea muy apreciada por ella misma, refiriendo incluso cómo en una ocasión la sacó de un apuro al sentirse humillada por los hombres que menospreciaban su trabajo en ese tipo de faenas. En aquellos tiempos el trabajo de la cholga seca acababa de introducirse en esa zona de los canales por los chilotes recién llegados, y ha sido la única manera de conservar y comerciar un producto del mar, a falta de cámaras frigoríficas. La eficacia del procedimiento de conservación, pese a la dureza del trabajo, ha hecho que perdure en el tiempo y sea el único trabajo regular en ese área que proporciona empleo, pero el monopolio existente genera una enorme injusticia a la vista de que a fecha de enero de 2009 tras haber hecho las debidas cuentas, si un trabajador durante mes y medio de faena consigue un rendimiento neto de 800 o 1000 pesos, el habilitador que negocia con la mercancía obtiene no menos de 3000 o 4000 pesos; si contamos que cada cuadrilla de tres o cuatro personas puede salir a la cholga unas tres veces al año y que el habilitador hace su negocio con 10 o 12 cuadrillas, podemos sacar los resultados de su beneficio. Raúl, el actual compañero o segundo marido de Doña Gabriela, como ella decía, decidió no salir más a trabajar en cuadrilla en ese oficio al estar desengañado por el duro trabajo del que no obtenía beneficio.

Año que trabajé cholga no, no hase que va comprar ropa, no, nunca; acá no se vende ropa tampoco. Cuando traía la cholga seca, ese lo entregaba todo a la persona que habilitó, que le dio la cosa, vívere, y noqueaba na, porque todo, te lleva do quintal de harina, no sé cuánto kilo de asúca, arró, fideo, to eso tenía que pagar con la misma trabajo, con la misma cholga, [...] así que igual que na, no alcansabapana; [...] Poreso que Raúl se cabreó y no salió má con la gente, no conviene mucho, no.

Situación que podemos ver también denunciada en la literatura (Martinic 2004: 244):

[...] Los kawéskar debieron soportar los abusos que con ellos, como con otros proveedores de productos de la localidad, ejercían los comerciantes locales que tenían el control del negocio de los mariscos.

\section{VALORES Y RELACIONES SOCIALES}

Doña Gabriela no tuvo una infancia fácil; huérfana a la edad de 8 años, a punto estuvo de ser adoptada contra su voluntad, o secuestrada más bien y sacada fuera de los canales, si no llega a estar atenta y reacciona a tiempo. Esta circunstancia tal vez jugó un papel decisivo para que en lo sucesivo mantuviera una actitud de alerta permanente, espíritu crítico y carácter rebelde. Las anécdotas que cuenta hace ver los miedos que por aquél tiempo existían sobre los loberos chilotes, al huir al bosque rápidamente por temor a ser raptada y quién sabe qué más; temores que también aparecen registrados en la literatura (Emperaire 1963:224-225; Bengoa 2004:583; Martinic 2006: 1280; CONADI 2007; Aguilera 2007). Sin embargo, el juego con amigas no kawésqar de su edad (Laidita y Liria) estuvo bastante presente en su infancia, sirviéndole esa experiencia intercultural, con juegos habitualmente de emulación de la vida cotidiana, para comenzar bien temprano el proceso de socialización con las personas venidas de fuera.

[...]se llamaba Liria, Laidita y la Liria, esa eran chilota. Esa do amiga era que siempre jugábamo. [...] hasíamo carpita, una carpita chiquitita,

En la actualidad reconoce tener un doble carácter con los demás: amable e irritable, según las circunstancias. Su personalidad abierta, hospitalaria y su disposición normalmente conversadora, se vuelve cerrada, colérica y verbalmente agresiva cuando le tocan la fibra sensible y se enoja con algo o con alguien, como nos decía. Los desengaños sufridos con las personas a lo largo de su vida y su avanzada edad hacen ver en su mirada un punto de incredulidad y un cierto grado de desconfianza que actúan como coraza autoprotectora.

Raúl me pedía, como tomaba senojaba no daba plata, así que yo tenía plata nunca quise dar plata a ello mientra salía tomar conotro gente, con chilote, ahí, pasaba to el día, no me venía picá un palo leña, nada, así que yo igual lo castigué, 
no quise dar ni una cosa, ni la comida, nada, ni lava la ropa, yo no iba está lavando ropa, yo no soy tan lesa, así que un día le dije: ya; [...]

Resulta interesante observar cómo las buenas vivencias e impresión favorable que le provocan algunas personas, se vuelve desfavorable a raíz de algún acontecimiento o con el paso del tiempo, ocurre con su prima Yolanda, algo mayor que ella, o con su antes amiga Esther Wellington. No se priva en señalar aquellos comportamientos que no le gustan de los otros e incluso de calificar a algunos como malas personas. En razón siempre a su testimonio, existen quizás dos tipos de conducta que detesta en los demás y se enorgullece de no participar de ellas, nos referimos a la mezquindad y al chismorreo. Tacha de mañoso o mañosa a quienes no son hospitalarios con las visitas y no ofrecen lo que tienen, ya se trate del vecino o de su propia hermana. Y le resulta especialmente enojoso entrometerse en la vida de los demás que no formen parte de la propia familia nuclear, como le ocurrió con Bete, la mujer del dueño del almacén de la ECA en Puerto Edén, al interrogarla sobre la posible relación amorosa de su marido con su prima. Dos tipos de conducta que hay que evitar al ir contra los valores que se desprenden de los antiguos kawésqar: solidaridad, es decir, repartir lo que se tiene (Emperaire 1963: 299; Gusinde 1991 [1974]:423-427; Barros \& Armstrong 1975:44; Kuzmanich 1980:96; Tonko 2008: 9); e independencia, evitar intervenir sin permiso en la vida de los demás (Emperaire 1963: 214-223; Gusinde 1991 [1974]: 169, 431).

El valor de la solidaridad es referido en la literatura a través del ya mencionado tčas, comportamiento institucionalizado a modo de ofrenda, dádiva o intercambio por el que se reparten alimentos cocinados entre las familias (Emperaire 1963: 228-229), y lo apreciamos en los numerosos episodios relatados, en donde doña Gabriela y quienes la acompañan comparten con el resto de parientes y demás familias del campamento el producto conseguido, ya sean peces o carne de caza, quedando a veces sin nada para uno; conducta a la que se sienten obligados por la enseñanza y el ejemplo que dejaron los mayores: hay que compartir los alimentos que se obtienen por poco que sea, como medida de seguridad social, bajo el principio de hoy por ti y mañana por mí.

[...] teníamoquempesar repartir a to lo carpa que tiene gente questabanahi, [...] Tu pasa dejar do, cuatro lobo a ello pa que coma ello, a resto pa otra gente; [...] ¿por qué lo repartimonosotro mismo sacrificamopa ir buscar, pa ir casar?, y ehpué yo no me quedaba sin na; claro, ese ahora que pienso esa cosa, yo me quedaba sin na, mirando cómo otro comía.

Principio tradicional del que se queja cuando observa que hay entre los suyos quienes no lo siguen, quienes por exceso de egoísmo no te invitan a tomar algo si vas de visita, o quienes se muestran reacios a acogerte en su casa, aún en caso de apuro o necesidad. Al margen de lo relatado, tuvimos suficientes pruebas para observar sobre el terreno que la insolidaridad también se manifiesta en la sociedad kawésqar, tanto entre los denominados urbanos (residentes en Punta Arenas y Puerto Natales) como autóctonos (residentes en Puerto Edén).

La independencia constituye por otro lado un rasgo característico del modo de ser de este pueblo, citado en la literatura, y claramente visible en lo narrado por Gabriela. La familia es el medio esencial de socialización, es en familia como se acostumbra viajar y los asentamientos en la práctica nómada son habitualmente familiares. Esa experiencia de vida independiente, relativamente solitaria y poco condicionada por los demás, desarrolla un acusado sentido de libertad y respeto por la vida privada de los demás. En consecuencia, el conflicto social, aunque se manifiesta en ocasiones, durante las estancias interfamiliares y sobre todo cuando la vida se vuelve más sedentaria y el asentamiento pasa a ser comunitario, no parece que fuera abundante. La escasez de conflictos entre kawésqar, su carácter pacífico, y la ausencia de líder, son factores que se hacen notar en la narración. En la dinámica familiar parece que el hombre tiene más capacidad de decisión que la mujer, es quien finalmente dice hacia dónde dirigirse; pero los papeles están repartidos y las decisiones son por lo común consensuadas, circunstancia que se puede deber, como señala Chapman (2004), al importante rol productivo que desempeña la mujer en la alimentación de la familia.

En Jetarkte-kstal, antiguo asentamiento comunitario de lo que ahora es Puerto Edén, no había ningún kawésqar al que se le reconociera su autoridad, aunque había diferencias en el prestigio social de unos y otros, no se aprecia diferencias significativas en las relaciones de poder. Son los 
aviadores de las FACH quienes lo ejercen, quienes son reconocidos y respetados por los kawésqar como autoridades. Observar cómo los kawésqar acatan sin rechistar las normas que los aviadores y los carabineros les imponen, cómo se muestran disciplinados, cómo piden su correspondiente zarpe antes de emprender un viaje, o avisar de lo que van a hacer en determinados momentos, no deja de ser significativo e interesante en un pueblo no acostumbrado a pedir permiso ni vivir sometido a jefe alguno. Entendemos que tal disposición a colaborar con la autoridad se debe en buena medida a la actitud de servicio que desde el principio ha mantenido dicha autoridad, caracterizada más por el reparto de víveres que por la coacción que sobre ellos pudieron ejercer.

La ausencia de jefe comunitario en la resolución de problemas y la independencia en la organización y dinámica social ya fue observada por Emperaire (1963: 215, 223), también en Puerto Edén:

[...] Los interesados son los únicos jueces que arreglarán, aun por la fuerza, un diferendo que no concierne al resto del grupo.

Los hombres arreglan sus diferencias entre ellos y las mujeres entre ellas, y nadie interviene en los asuntos ajenos.

[...] Actualmente, no hay por encima del jefe de familia ningún jefe de grupo y parece que ha sido siempre así. [...] Esta ausencia de jefe es igualmente mencionada por Darwin. El grupo actual está formado por la simple yuxtaposición de familias independientes. Ninguna autoridad viene a interponerse entre el grupo y las familias.

En todo el relato solo su primo Lautaro Edén (sobrino de su madre) aparece como líder de un pequeño grupo, por poco tiempo, dada su desaparición, aunque hay que considerar que fue una persona educada y adiestrada durante su juventud en una institución militar y por tanto acostumbrada a la jerarquía y al ejercicio de mando. Las familias independientes o los grupos de familias que navegaban por los canales consentían ser conducidas por las personas mayores que tenían más experiencia y conocimiento, las cuales ejercían un papel de guía y no de jefe, ya que nadie estaba obligado a seguirlas, y todos opinaban, daban su parecer, como observamos en la narración.

[...] justed tenía que embarcarse con éste, vamo ir tal parte, ahora vamo salir!, disía (Lautaro), jvamo pasar campamento antiguo!, él sabía to el puerto, iy ahí vamo quedar!. Claro, y así fue, [...]. iTenemo que salí temprano!, desía, lleguemo temprano a isla Cangrejo; ya vamo sali disía no má, nosotrovamocambiá otra costa,

En cuanto a los conflictos, según su versión, son los chilotes, los venidos de fuera, incluidos los aviadores, quienes lo provocan, y los kawésqar lo contemplan a distancia sin querer inmiscuirse. Incluso su primo Zambrano, en una ocasión, renuncia a reclamar el dinero que le debían de la tala de madera en Puerto Edén, para evitar meterse en la pelea que disputan quienes tenían que pagarle. Ella misma describe la única pelea que tuvo durante su infancia con su amiga Laidita, como un acontecimiento vergonzoso que jamás volvería a repetir, aunque no lo provocara tampoco en ese caso.

[...] éste no mestá jugando bien mestá peleando, así que yo igual lo agarré, lo tiré el piso, le pegó tol cubo, empesóreclamame, tie miedo; claro yo era coarde, yo era coarde; así que yo le dije: jchuta!, creiendo que su mamá me ia retar (regañar) o me ia pegar, to esa cosa lo pensé, siempre macuerdodeso, ya nunca má juego, claro siempre jugamo bien, pero esa fue primera ve que me pescó ese y lo agarré también, y ahí nunca má, nunca he peleao, nunca me peleao con mi mihma amiga compañera, nada, nunca, eso fue lo bueno que fue, hasta la fecha, yo no me gusta buscar boche [conflicto] con otro, no, prefería yo ando tranquila.

En general, las relaciones de la población kawésqar con los aviadores de las FACH y los carabineros en Puerto Edén eran mutuamente respetuosas e incluso amistosas, al menos con los primeros, excepción hecha de algún que otro incidente como el ocurrido con un carabinero al que doña Gabriela encargó en varias ocasiones que le hiciera llegar a su hijo José, que residía en ese momento en Punta Arenas, una mochila, unas cartas y algo de dinero, y jamás llegaron a su destino, lo que fue una prueba más para desconfiar de todos.

[...] muy confiao fue que lo mandé, mandé plata aentro, carta, y como lo chico estaba lugar de lo carabinero, así que pa salir, pacomprá alguna cosa tenía que tener platita siempre, mandé plata, enese tiempo plata era escudo, era harta plata, no sé cuánto escudo habrá sido, a lo carabinero lomandé, con la persona que yo trabajaba, claro, 
ese, yo fui tonta, esa mochila cuánto la gente le estaba cuiseandopo, pucha Gabriela, véndemelo ese mochila, lo quería, igual tenía su hija estudiando Punta Arena, igual, así que desía: véndemelo, yo lo compro pa mi hija, pa la Mónica, questá a Punta Arena. Claro, yo pura tonta se lo pasé a ello mismo que me estaba comprando, como quedó su hermano, y la mala suerte que la plata no lo resibió y la mochila tampoco, nada. Le mandé la carta, ahí desía te mando mochila, cuanto mil peso, qué carta vana entregar si no entregó la mochila. La mochila era pa José, pa José era, así que se perdió esa mochila dese buque.

Con la población chilota de ese lugar, a juicio de doña Gabriela, no parece que las relaciones fueran del todo bien. Excepto con la familia de don Manuel (actual dueño de tienda) y la señora Tato (su mujer) con la que traba una amistad duradera hasta hoy, presenta diversas situaciones en donde el menosprecio, la dominancia, y los abusos laborales hace que mantenga las distancias y un trato receloso con los demás Actualmente las relaciones, tal como se recoge en el relato y pudimos comprobar personalmente, sin llegar a ser inamistosas, poseen un elevado grado de indiferencia mutua. Los kawésqar se quejan de lo poco que les han aportado los chilotes personalmente, de la competencia desleal que sufren en la comercialización de su artesanía, de ser considerados inferiores; $y$ los chilotes protestan por entender que la población kawésqar recibe un trato de favor de parte de las instituciones que aportan ayuda, sintiéndose ellos mismos discriminados. En cualquier caso y a pesar de los reproches mutuos, unos y otros se sienten desprotegidos y abandonados por un Estado chileno que les tiene en el olvido, circunstancia también señalada por Martinic (2004: 23) al referirse al aislamiento geográfico y al abandono de facto por la acción gubernativa.

Caso aparte es el de la población minera de Guarello con quienes, además de las relaciones laborales, mantuvieron lazos de amistad, reconociendo al mismo tiempo el comportamiento solidario que tuvieron con ellos en todo momento, como lo demuestra la colecta realizada para recaudar dinero que le permitiera acompañar a Raúl, su actual marido, hasta Punta Arenas donde tenía que ser hospitalizado y operado.

[...] doctor llegó y dijo: su maríotenemo que mandar a Natale, dijo, porque, éste, su mano está hinchá, va pillar gangrena y errepente va perder su mano, así que mejor era hospital, dijo. Yo le dije: ¿puedo hacer una pregunta?, dije, ¿yo qué voy haser acá sola, me puedo ir conello?, le dije. Claro, dijo, si quiere váyase no má, nosotrovamo hacer una colecta. Claro, hiso una colecta y empesó reunir la plata a to lo, a to lo minero, y así fuimo, fuimo lo do.

En cuanto a las relaciones sociales con los pocos kawésqar que, como ella, residen en Puerto Edén, la situación no es muy satisfactoria. Además de la observación personal sobre el terreno que lo corrobora, su testimonio cargado de reproches deja ver que si bien con unos las relaciones son muy afectuosas, con otras no solo son indiferentes sino de enemistad manifiesta, circunstancia que ni ella misma llega a entender muy bien, pero que achaca a la envidia que algunas vecinas le tienen por ser tan emprendedora y obtener regalos y recursos que otras no consiguen.

Envidia es que tiene, envidia. Ese tiempo cuando me regaló ese congelador, ese fue un regalo que me hiso la señora de Scorpio (un buque) que andaba, hija de capitán, el día la Pascua fue este tiempo fue, [...] Claro, poresa cosa se armó tremendo comentario, nojándome, que había mandao carne, de to, no sé cuanto kilo carne me mandó esa señora. Y ese porese me tiene mal, no sé por qué sería, claro; así que poreso yo nunca llego ahi, nuunca, tampoco cuando me falta alguna cosa: asúcar, un kilo yerba, tampoco, yo no, no quiero cuenta conella, nada, esa gente no.

Impresión que no coincide con la de Gusinde (1991 [1974]:405) al decir de los kawésqar (halakwulup) que conoció en la península Muñoz Gamero:

No envidian en absoluto a ningún miembro de la etnia, y lo que es más, tampoco a las cosas que posee; [...] La conducta de estos indígenas se basa fundamentalmente en el principio de que quien necesita algo, tiene un claro derecho a la ayuda de los otros.

$\mathrm{Y}$ no son mejores las relaciones que mantiene con sus parientes de Punta Arenas, de quienes no quiere saber nada, al sentirse mal entendida e incluso despreciada en algún caso por las situaciones que narra.

A parte de mi hija tengo prima (en Punta Arenas), ella vive aparte de la comuniá (Fresia 
Alessandri), tiene casa particular que compró ella, o quisá su hermano la abría comprao, tremenda casarone que tiene ella. [...] Vivía serquita donde está mi hija, donde está la Mersé; no sé por qué, y sabe que una talla que me hiso fue ella: cuando, ese día estaba to su hijo, su hija, su yerno, y su nieto, su nieta, y me resiben con mala gana, para ella parese que fuera que no me servía, me dejaron sola a una parte, y ese me sentí mal po, claro, porese motivo no llegué má.

Relaciones rotas y falta de interés por recuperarlas, lo que reduce su ámbito familiar al de sus hijos e hijas. Como comenta, cuando viaja en el buque a Puerto Natales, solo visita a su amiga chilena en cuya casa pernocta, ignorando a los kawésqar que allí residen.

[...] yo voy a Natale donde persona que me quiere, entonse ahí quedo, si quiero salir salgo conella.

Lo cierto es, al margen del relato, que en el conjunto del pueblo kawésqar el enfrentamiento y rivalidad entre familias resulta algo común, no exclusivo de la familia Tonko Paterito (la de Doña Gabriela), aunque por ser ésta una familia hegemónica que representa en estos momentos el principal referente de su propia cultura, la pone en el punto de mira de todas provocando el respeto y admiración de unas y el recelo y crítica de otras.

Esta situación de desencuentro social e interfamiliar que define la actualidad kawésqar, no la apreciamos tan acusada en el pasado que queda reflejado en algunos relatos históricos (Gusinde 1991 [1974]: 406; Vega 1995: 27), en donde las opiniones desfavorables que se vierten sobre las personas no impide hablar con ellas, visitarlas sin necesidad de llegar a romper relaciones, como ocurre ahora. Emperaire (1963: 223), sin embargo, ya destacaba, no hostilidad, pero sí un elevado grado de indiferencia en las relaciones sociales:

No se puede casi hablar de sociedad al referirse a esta reunión artificial creada en Edén desde fuera, a esta agrupación que, junto con desaparecer, se desmembra y rompe con la tradición. Una parte de los alacalufes no tiene otras relaciones con el grupo que el lenguaje y la pertenencia, pero no se sienten ligados a él. [...] la unidad básica del grupo, es la familia, en sentido estricto, cuyos lazos se fundan en la consanguinidad real,

En contrapartida podemos observar enormes muestras de adhesión desinteresada hacia las personas que se quieren o a las que se les tiene gran aprecio; por ellas no escatiman hacer cualquier tipo de sacrificio. José Tonko, por ejemplo, deja de repente el trabajo en Guarello y junto con Gabriela (su mujer) acuden a la llamada de un familiar que reside en Puerto Edén, sin saber exactamente de qué se trataba, para lo cual tuvieron que remar durante más de una semana. En otra ocasión, José (hijo de Gabriela) y el hermano de Raúl (su actual marido) no dudan en ir con la chalupa en busca de su madre que atendía la casa de Medina (dueño del almacén de EMASA) por la noche en pleno temporal para traerla a su propia casa. Por otro lado, su primo Zambrano, ejemplo de buena persona, ofrece permanentemente muestras de compañerismo y amistad allá donde esté. En definitiva, pese a la actitud distante que algunas familias y personas tienen entre sí en estos momentos, y a la crítica que se vierte sobre el egoísmo de algunas, el relato histórico en torno a su vida personal está repleto de fuertes lazos entre las personas, de contraprestaciones altruistas que demuestran a quienes las reciben que no se encuentran solas y siempre hay alguien que piensa en ellas y con las que en todo momento pueden contar.

[...] Finao Sambrano no tenía mujer, era una persona de edá, ya, y estaba con nosotro; en la isla Guarelo tenía su ranchito aparte y vivía solo, siempre ese hombre era trabajaor, to el tiempo salía a trabajar, a mariscar, a buscar leña, se iba pal monte, traía una cargamento leña, alumbraba to esa cosa, ese siempre ha sio buena gente ese finaito, siempre yo cuando enfermó cuánto lo cuidé; harto ayudó a nosotro ese hombre, como él era solo, no tenía familia, no tenía nada, yo namá era pa él una familia, poresoto el tiempo ehtaba con nosotro, toelaño, ahí ehtaba los do la isla.

La vida en los canales, pese a su dureza, ofrece también muchos momentos para sonreír y estar alegres, aunque llama poderosamente la atención la ausencia de tiempo de fiesta en la biografía de Doña Gabriela. No aparece en el relato, aunque insistimos en ello, ni una sola ocasión que por propia iniciativa las familias kawésqar se reúnan para celebrar o festejar algún acontecimiento. Tampoco escuchamos en su testimonio manifestaciones de canto, música o danza que realizaran en el pasado, como se puede leer en el trabajo de la musicóloga M. Ester Grebe (1974), 
y menos aún rituales de carácter iniciático como el kalakai, referido en Barrientos (2006:119). La fiesta, el tiempo de encuentro comunitario dedicado al comensalismo colectivo y al disfrute social, la aportan siempre los chilotes o los aviadores en Puerto Edén, o bien los mineros en Guarello, por distintos motivos: fiestas patronales, fiestas patrias, celebraciones familiares. Incluso la celebración del bautismo de su hija María Isabel fue organizado por el padrino y mineros chilenos en Guarello.

[...]la María Isabel la bautisamo ahí, y un minero que había conosío, él se hiso padrino, él lo pidió; y ahí lo bautisamo.

La fiesta, a juicio de doña Gabriela, no es contemplada como algo tradicional entre los kawésqar y, como nos dice: la fiesta es cosa de ellos (refiriéndose a los aviadores y chilotes). De sus dos matrimonios nada contó acerca de posibles celebraciones.

Vida de permanente trabajo la suya, no solo aprendió todo lo necesario de sus mayores, de su propia cultura para sobrevivir en los canales, sino que también se preocupó por aprender a coser, tejer, hacer artesanía, como recursos para ganarse la vida, ante el nuevo modelo que se imponía, adaptado a la sociedad nacional dominante. Pese a lo asustadiza que se mostraba en su infancia, temerosa de lo que oía decir de los loberos chilotes, de las borracheras, con el tiempo forjó una fuerte personalidad. Yo he pasado mucho, decía; además de las numerosos momentos de peligro e incluso hambre experimentados en la navegación por los canales, vivió bastante tiempo alejada de su primer marido, al que mucho le reprochó por su falta de atención, teniendo que sacar adelante ocho hijos, y sentir el fallecimiento de dos de ellos. No darle importancia a los dolores del parto cuando le preguntamos por ellos da pruebas de su fortaleza, al parecer había otros dolores mucho mayores por los que preocuparse. Sin embargo y pese a todo, mantiene una visión irónica de la vida, chistosa en muchos casos; en no pocas ocasiones de su relato sonríe e incluso se echa a reír al recordar ciertas situaciones con hilaridad, no lo puede remediar, bromea con frecuencia, se burla con gracia de la persona que le enseña a hacer café con harina de trigo o sopaipilla por primera vez.

[...] errepente ese hombre Miranda que digo yo, ese chilote, empesó a ser, empesó conversar: ¡vamo a ser café, yo voy a ser un café! Yo como era intruso buscaba teboche (broma), no, yo lo molestaba ese hombre, ¿cómo era? yo lo molestaba: ¿qué café va a hacer tu? ¿ónde lo iba sacar? ¡Bueno, déjame no má, si yo sabré que lo voy a haser! (le decía Miranda); claro. [...] Yo era que molesteba ya, yo; el finao José se reía no má. [...] empesamo servir to; qué rico era eso, ipucha!, y ahí mismo me molestaba, como yo lo molestaba, él igual me molestaba. Dijo: ¿cómo está, está malo o está bueno? Yo desía: está bueno.

Mujer que ha pasado mucho, como nos recuerda, pero que también tiene bastantes motivos de alegría para compensar sus penas. Aunque pesimista sobre el futuro de la sociedad y la cultura kawésqar, que entiende están abocadas al olvido, su vida sin duda dejará una notable huella, no solo por lo más importante, que es su extensa descendencia, sino también por el recuerdo de quienes tuvieron ocasión de compartir con ella, y esperamos que por el testimonio biográfico aquí recogido.

\section{MENTALIDAD Y CAMBIO SOCIAL}

No encontramos en el relato elementos suficientes que nos hablen sobre la cosmovisión, sobre las ideas de la protagonista en torno al mundo trascendente, aunque durante las conversaciones coloquiales al margen manifestó de modo explícito su incredulidad acerca del más allá, después de la muerte no hay nada más, nos decía, todo acaba ahí, no vamos a ninguna parte. Las vagas ideas que le llegó de la doctrina católica poco o ningún efecto hizo en ella, como en el resto de los kawésqar de Puerto Edén, en donde permanece levantada una pequeña iglesia, ahora sin párroco, que fue asistida en el pasado por el misionero jesuita Vaeremaecker. En su vivienda no hay signo alguno de orientación cristiana. Tan solo un objeto del Niño Pascuero (o Papá Noel), personaje laico de influencia anglosajona, cuelga de la pared como símbolo de la Navidad, aunque poco caso se le hace.

De su relato y del trato directo con ella se desprende, eso sí, como ya hemos comentado, una mentalidad aventurera, sin dejar de ser prudente, predispuesta al viaje, resistente, con capacidad de aguante, adaptada para hacer frente a cualquier tipo de incertidumbre, hospitalaria, abierta y conversadora, reflexiva, dominante, con estados de ánimo variables 
(alegres y tristes) aunque por lo general equilibrado.

Sensible a todo aquello o con todo aquél que quiere, sintió mucho como madre la muerte en el hospital de Punta Arenas de su hijo Roberto, aquejado de una enfermedad; pero su sinceridad la lleva a no tener reparo en manifestar la indiferencia que le causó tanto la muerte de su marido José como la de su hijo Patricio, ambos calificados de mañosos por lo que la hicieron sufrir.

Yo no me sentí mucho de cuando se falleció José y porque se portaba muy mal con nosotro.

Así que, yo no sentí nada [por la muerte ahogado en el mar de Patricio], así que como no me quería yo tampoco no lo quería, porque era mañoso, entonse qué sentío iba tener conél, nada, lo miraba como una persona estraña, nada, nada, así que no.

De sus palabras apreciamos por otro lado una forma de ser poco materialista, no posesiva, desprendida de todo aquello que resulta superfluo y puede llegar a ser incluso incómodo para una persona acostumbrada a cambiar con frecuencia de residencia y hacer del viaje un modo de vida. Sin embargo, aunque sigue compartiendo lo que tiene con todo aquél que llega a su casa, y el viaje forma parte de su imaginario, el paso del tiempo y su edad la han fijado a un lugar (Puerto Edén) y se ha rodeado en su hogar de todos aquellos utensilios y electrodomésticos (refrigerador, sofá, bañera, etc.) que le proporciona una mayor comodidad, lo cual constituye una significativa prueba del cambio experimentado en su vida.

De lo vivido en el pasado le queda la memoria, una gran capacidad para recordar y reproducir con palabras su experiencia y la experiencia de su pueblo, las maneras de hacer y de pensar que, como nos cuenta, ya no volverán jamás. Ante nuestra insistencia de darle importancia a su memoria, y a registrarla por escrito, ella insiste a la vez en restársela y en un tono pesimista y melancólico nos dice que no vale para nada, que a nadie importa y se olvidará cuando ella se marche definitivamente junto a los mayores de su generación.

Pese a su opinión, lo cierto es que ha sido testigo privilegiado de un período, el que va de mediados del siglo XX a la actualidad, marcado por un proceso intenso de cambios, los cuales han propiciado la pérdida casi completa de su cultura, la pérdida de los usos y costumbres que aprendió en su infancia. Uno de los principales valores que tiene su historia de vida es precisamente el hecho de permitirnos observar y entender las consecuencias del cambio, cómo se fueron produciendo, quiénes fueron los agentes inductores, qué reacciones provocaba y qué consecuencias trajo consigo. Resulta muy sugerente, sobre todo por el retrato que hace de cada acontecimiento y del contexto o circunstancias que lo envuelven, los detalles que ofrece sobre sus reacciones cuando por primera vez descubre el mate, con su amargor; o el charqui, la carne seca que por desconocimiento le dan por saco a los perros; el gusto por la sopaipilla; la sorpresa al preparar harina de trigo tostada como sucedáneo del café; la incomodidad de sus primeros zapatos, regalados por un minero en Guarello, padrino de bautizo de su hija María Isabel; el aprendizaje sobre prácticas de higiene (lavarse, peinarse, cambiarse) siguiendo las sugerencias de los aviadores; el aprendizaje del secado de cholgas y la explotación que la acompaña; la introducción de la chalupa y redes para pescar, así como la escopeta para cazar; la asistencia de los hijos al colegio y el temor a que otros chicos los insulten o maltraten; el descubrimiento del dinero (los escudos) para hacer transacciones.

Su testimonio nos hace ver cómo de ir a pata pelá, como ella dice, buscando permanentemente el sustento en los productos del mar, sin un lugar fijo de residencia, y en compañía de su familia o pequeño grupo de viaje; pasa a depender progresivamente de quienes llegan de fuera: aviadores que les proporcionan víveres gratuitamente en Puerto Edén, en donde se instalan almacenes de alimentos (ECA y EMASA), madereros y empresa minera que ofrecen trabajo en Guarello, buques mercantes que van de paso con quienes intercambian y reciben regalos. Del nomadismo aún vigente a mediados del siglo $\mathrm{XX}$, se pasa al sedentarismo y pérdida del hábito del trabajo con la llegada de las FACH a Puerto Edén y/o el éxodo fuera de los canales para vivir en la ciudad de Punta Arenas o Puerto Natales. Nos describe en definitiva el proceso de asimilación social y cultural que los kawésqar han experimentado durante los últimos 70 años. Asimilación que conduce por múltiples caminos, como se puede ver en su propia familia y a través de sus hijas e hijos, los cuales han tomado rumbos bien distintos. Asimilación que alcanzó tanto a quienes migraron a la ciudad como a quienes quedaron en Puerto Edén. En cuanto a estos últimos, no todas las familias consiguieron subsidios del Estado, una pequeña paga vitalicia con la que ayudarse; no todos fueron 
igual de emprendedores, ni Puerto Edén cumplió con las expectativas de desarrollo que suponían tendría. La falta de expectativas, unida a la explotación de las personas por parte de los más oportunistas, y la desilusión colectiva, hizo que el alcohol cobrara protagonismo como aliviadero de frustraciones $y$ provocara estragos en buena parte de la población, tanto en hombres como en mujeres, lo cual ha constituido y constituye en la actualidad un importante elemento de desestructuración familiar y social.

\section{CONSIDERACIÓN FINAL}

La historia de vida de doña Gabriela Paterito es una narración densa, reflexiva y sincera, tres características importantes para darle fiabilidad y rigor etnográfico, que corrobora en parte lo expresado por Emperaire (1963) y Gusinde (1991 [1974]), así como también se separa o distingue de ellos en algunos aspectos, como hemos tenido ocasión de mostrar. Repleta de detalles, nos ofrece una ocasión para viajar con ella por su pasado, para visitar los lugares por donde pasó, conocer a las personas con quien estuvo y compartir sus aventuras; pero además nos acerca su pensamiento, su manera de ver las cosas; nos ayuda a entender su forma de razonar y de sentir, con las contradicciones que son propias de cualquier ser humano pero expresadas de manera clara y honesta. Su estimulante biografía, de la que aquí registramos solo algunos de los episodios más significativos, constituye un relevante testimonio histórico para toda aquella persona que desee conocer las vicisitudes de una época y de un pueblo en su última fase de colonización cultural por la sociedad dominante, y es por ello por lo que nos atrevemos a contradecir sus palabras para expresar y poner en valor su inapreciable memoria.

\section{BIBLIOGRAFÍA}

Aguilera, O. (2001). Gramática de la lengua Kawésqar. Santiago de Chile: Corporación Nacional de Desarrollo Indígena (CONADI).

(2007). Lenguas y culturas de Chile. Recuperado de http://www.kawesqar.uchile.cl/cultura/index.html

Aspillaga, E., Ocampo, C., \& Rivas, P. (1999). Restos óseos humanos de contextos arqueológicos del área de isla Navarino: indicadores de estilos de vida en indígenas canoeros. Anales del Instituto de la Patagonia, 36, 123-135.
Barrientos, F., Álvarez, J., Mege, P., Gómez, A., Vicens, R. \& Morales, M.T. (2006). Origen y actualidad de los pueblos indígenas de Chile. Santiago: CONADI/Unidad Académica de Humanismo Cristian.

Barros, A. \& Armstrong, E. (1975). Aborígenes Australes de América. Santiago: Editorial Lord Cochrane.

Bengoa, J. (2004). Los pueblos canoeros del sur. En J. Bengoa (Ed.) La memoria olvidada. Historia de los pueblos indígenas de Chile. Santiago: Cuadernos Bicentenario.

Cárdenas, R., Montiel, D. \& Grace, C. (1993). Los Chonos y los Veliche de Chiloé. Santiago: Ediciones Olimpo.

Clairis, Ch. (1985). El qawasqar. Lingüística fueguina. Teoría y descripción. Valdivia: Estudios Filológicos.

Coiazzi, A. (1914). Los Indios del Archipiélago Fueguino. Santiago: Imprenta Universitaria.

CONADI (2007). (Generalidades etnográficas kawésqar). Recuperado de http://es.wikipedia.org/wiki/Alacalufe.

Córdoba, A. de (1787). Relación del último viaje al Estrecho de Magallanes de la fragata de S.M. Santa María de la Cabeza. Madrid: Archivo del Museo Naval, Colección Vargas Ponce.

Chapman, A. (2004). Breve historia de los Yamanas desde fines del siglo XVI hasta nuestros días. En C. Odone \& P. Mason. (Eds.) Mundos Fueguinos.12 miradas sobre selknam, yaganes y kawésqar (pp. 210-216). Santiago: Taller Experimental Cuerpos Pintados.

Chapman, A. (2003). El fenómeno de la Canoa Yagán. Viña del Mar: Conferencia Universidad Marítima de Chile.

Darwin, Ch. (1997 [1921]). Darwin en Patagona y Tierra del Fuego. (De la obra Viaje de un naturalista alrededor del mundo: 1840-43). Punta Arenas: Editorial Atelí.

De Agostini, A. (1929). Mis viajes a Tierra del Fuego. Milán: Editorial Prof. G. de Agostini.

Emperaire, J. (1963). Los nómades del mar. Santiago: Ediciones de la Universidad de Chile.

Garfinkel, H. 1967. Studies in Ethnomethodology. Englewood Cliffs, NJ: Prentice-Hall.

Goiri, R. (1997). La historia de los Kawashkar. Punta Arenas: Ediciones de la Universidad de Magallanes.

Grebe, M. E. (1974). La música alacalufe: aculturación y cambio estilístico. Revista Musical Chilena, XXVIII, 126-127, 80-111.

Gusinde, M. (1989 [1939]). Los Indios de Tierra del Fuego. Tomo IV. Antropología Física. Buenos Aires: Centro Argentino de Etnología Americana (CAEA).

Gusinde, M. (1951). Hombres primitivos de Tierra del Fuego. Sevilla: Publicaciones de la Escuela de Estudios HispanoAmericanos de Sevilla.

Gusinde, M. (1991 [1974]). Los indios de Tierra del Fuego. 
Tomo III (1 y 2) (Los Halakwulup). Buenos Aires: CAEA.

Harre, R. \& De Waele, J.P. (1979). Autobiography as a psychological method". En G.P. Ginsburg. (Ed.) Emerging Strategies in Social Psychological Research. New York: John Wiley\&Sons.

Laming-Emperaire, A. (1972). Los sitios arqueológicos de los archipiélagos de Patagonia Occidental. Anales del Instituto de la Patagonia, 3 (1-2), 87-96.

Lausic, S. (1993). Gentes de la Patagonia. Bandas aborígenes patagónicas y fueguinas: chonos, kaweskar, aonikenk, selk'nam, haus, yámanas. Punta Arenas: Editorial Atelí.

Legoupil, D. (1985-86). Los Indios de los archipiélagos de la Patagonia. Un caso de adaptación a un ambiente adverso. Anales del Instituto de la Patagonia, 16, 35-52.

Legoupil, D. (1997). El Poblamiento marítimo en los archipiélagos de Patagonia: núcleos antiguos y dispersión reciente. Anales del Instituto de la Patagonia, 25, 75-87.

Legoupil, D. (2000). El sistema socioeconómico de los nómades del mar de Skyring (Archipiélago de Patagonia). Anales del Instituto de la Patagonia, 28, 81-119.

Manzo, L. et al (2002). Los pueblos indígenas de Chile. Material de apoyo a la educación intercultural bilingüe. Santiago: Gobierno Regional Metropolitano.

Martinic, M. (1989). Los canoeros de la Patagonia meridional. Población histórica y distribución geográfica (siglos XIX y XX). El fin de una etnia. Journal de la Société des Américanistes, 75, 35-61.

Martinic, M. (1999). La inmigración chilota en Magallanes. Apreciación histórica sobre sus causas, características y consecuencias. Anales del Instituto de la Patagonia, $36,27-47$.

Martinic, M. (2004). Archipiélago Patagónico. La última frontera. Punta Arenas: Ediciones de la Universidad de Magallanes.

Martinic, M. (2006). Historia de la Región Magallánica. Tomo
I, II, III y IV. Punta Arenas: Ediciones de la Universidad de Magallanes.

Massone, M. (1987). Las culturas aborígenes de Chile austral en el tiempo. En VV.AA. (Eds) Hombres del Sur: aonikenk, selknam, yámana, kaweshkar (pp. 11-47). Santiago: Museo Chileno de Arte Precolombino.

Piana, E. L. \& Orquera, L. A. (2004). Los canoeros del extremo sur: arqueología de los archipiélagos magallánicosfueguinos. En C. Odone \& P. Mason. (Eds) Mundos Fueguinos.12 miradas sobre selknam, yaganes y kawésqar (pp. 169-190). Santiago: Taller Experimental Cuerpos Pintados.

Radin, P. (1920). The Autobiography of a Winnebago Indian. University of California Publications in American Archaeology and Ethnology, 16(7), 381-473.

Radin, P. (1926). Crashing Thunder, The Autobiography of an American Indian. Nueva York: Appleton.

Sarabia, B. (1986). Documentos personales. En M. García (Ed.) El análisis de la realidad social. Métodos y técnicas de investigación (pp. 187-208). Madrid: Alianza Universidad Textos.

Simmons, L.W. (1942). Sun Chief: The Autobiography of a Hopi Indian. New Haven: Yale UniversityPress.

Thomas, W.I. \& Znaniecki, F. (1918-1920). The Polish Peasant in Europe and America. Boston: Richard G. Badger.

Vairo, C. (2007 [1995]). Los Yamana. La tradición marítima de los aborígenes de Tierra del Fuego. Ushuaia: Zagier \& Urruty Publications.

Vega, C. (1995). Cuando el cielo se oscurece (Samán arkachoé). Historia de vida, testimonio alakalufe de Alberto Achacaz Walakial. Punta Arenas: Editorial Atelí.

Vega, C. \& Grendi, P. (2002). Vejámenes inferidos a indígenas de Tierra del Fuego. Tomo III. Punta Arenas: Corporación Nacional Indígena de la XII ${ }^{a}$ Región.

Corporación Nacional Indígena de la XII ${ }^{a}$ Región. 
